\title{
Halophyte Plants and Their Residues as Feedstock for Biogas Production-Chances and Challenges
}

\author{
Ariel E. Turcios ${ }^{1}$ (), Aadila Cayenne ${ }^{2}$, Hinrich Uellendahl ${ }^{2}$ and Jutta Papenbrock $1, *$ (I) \\ 1 Institute of Botany, Leibniz University Hannover, Herrenhäuserstr, 2, 30419 Hannover, Germany; \\ a.turcios@botanik.uni-hannover.de \\ 2 Faculty of Mechanical and Process Engineering and Maritime Technologies, \\ Flensburg University of Applied Sciences, Kanzleistr, 91-93, 24943 Flensburg, Germany; \\ aadila.cayenne@hs-flensburg.de (A.C.); hinrich.uellendahl@hs-flensburg.de (H.U.) \\ * Correspondence: papenbrock@botanik.uni-hannover.de; Tel.: +49-511-762-3788
}

Citation: Turcios, A.E.; Cayenne, A.; Uellendahl, H.; Papenbrock, J.

Halophyte Plants and Their Residues as Feedstock for Biogas

Production-Chances and

Challenges. Appl. Sci. 2021, 11, 2746. https://doi.org/10.3390/app11062746

Academic Editor: Elena Tamburini

Received: 28 February 2021

Accepted: 16 March 2021

Published: 18 March 2021

Publisher's Note: MDPI stays neutral with regard to jurisdictional claims in published maps and institutional affiliations.

Copyright: (c) 2021 by the authors. Licensee MDPI, Basel, Switzerland. This article is an open access article distributed under the terms and conditions of the Creative Commons Attribution (CC BY) license (https:/ / creativecommons.org/licenses/by/ $4.0 /)$.
Abstract: The importance of green technologies is steadily growing. Salt-tolerant plants have been proposed as energy crops for cultivation on saline lands. Halophytes such as Salicornia europaea, Tripolium pannonicum, Crithmum maritimum and Chenopodium quinoa, among many other species, can be cultivated in saline lands, in coastal areas or for treating saline wastewater, and the biomass might be used for biogas production as an integrated process of biorefining. However, halophytes have different salt tolerance mechanisms, including compartmentalization of salt in the vacuole, leading to an increase of sodium in the plant tissues. The sodium content of halophytes may have an adverse effect on the anaerobic digestion process, which needs adjustments to achieve stable and efficient conversion of the halophytes into biogas. This review gives an overview of the specificities of halophytes that needs to be accounted for using their biomass as feedstocks for biogas plants in order to expand renewable energy production. First, the different physiological mechanisms of halophytes to grow under saline conditions are described, which lead to the characteristic composition of the halophyte biomass, which may influence the biogas production. Next, possible mechanisms to avoid negative effects on the anaerobic digestion process are described, with an overview of full-scale applications. Taking all these aspects into account, halophyte plants have a great potential for biogas and methane production with yields similar to those produced by other energy crops and the simultaneous benefit of utilization of saline soils.

Keywords: anaerobic digestion; biogas production; Chenopodium quinoa; co-digestion; Crithmum maritimum; halophyte composition; inoculum adaptation; plant physiology; Salicornia europaea; salinity; Tripolium pannonicum

\section{Introduction}

The increase in global population and living standard has caused an increase in the demand for food, energy, soil and water, among other resources, and has led to an overexploitation of natural resources. Crop production globally suffers severe constraints as arable lands are diminishing because of soil salinization as well as freshwater scarcity due to the lack of precipitation and improper water resource management practices by the users. Salt-affected soils occur on all continents and under almost all climatic conditions. Approximately $43 \%$ of the land mass of earth is arid or semi-arid and $98 \%$ of its water is saline. Worldwide, over 800 million hectares are affected by salinity, 20\% of the 230 million hectares of prime irrigated agricultural land has become saline and the salinity threat is inching into arable lands [1].

Most salt-affected soils are found in arid and semiarid regions compared to humid regions. Salinization of agricultural land affects a considerable area of irrigation projects. Currently, salt is degrading $20 \%$ of the world's irrigated land and causing economic losses of around US\$27.3 billion per year, according to the assessment from the United 
Nations University [2]. This leads to investigation and promotion of environmentally sound practices and techniques to avoid further salinization, as well as research and use of salt-tolerant plants (halophytes) to produce food, feed and other marketable products, including renewable energy from biomass.

Halophytes have a substantial potential to restore salt stressed lands and in phytosanitation or phytoremediation of contaminated soils [3]. Saline land areas or marginal zones are rich in halophytic vegetation, which can thrive in high salinity environments. Dissimilar to glycophytes that are unable to ideally grow even in low salinity levels, halophytes can grow and complete their life-cycle in a salt concentration of at least $200 \mathrm{mM}$ $\mathrm{NaCl}$ [4], and some of them need salt for optimal growth (true halophytes). Therefore, they are potentially ideal candidates for bioenergy crops from saline soils. Halophytes can also be supplied with seawater without jeopardizing their biomass or seed productions, ultimately ensuring food security in several saline affected land areas, and the residues can be used for biogas production. Consequently, cultivation and valorization of halophytes is gaining developing recognition, more specifically in arid areas in which short supply of freshwater drives people to use marginal resources like brackish water. Hence, the cultivation of halophytes may be beneficial due to them being more economical to cultivate as well as being generally copious on saline soils. Furthermore, the sustainable processing of halophytic biomass to attain a wide range of marketable food and feed ingredients, high-value bio-based/bioactive products and bioenergy (biofuels, power and/or heat) allows for the optimum potential utilization of all viable feedstock components considering the availability of efficient methods of conversion and valorization [5].

In this context, biogas production from halophyte plants or their residues after processing of other valuable products offers an environmentally sound process combining production of renewable energy from biomass with recycling of plant nutrients and humus. Furthermore, biogas technology is a versatile technology that can be applied to a variety of biomass resources, in mono- or co-digestion and at different scales, from single households and farms to industry scale. Through this review paper, we would like to give an overview on the potential of using halophytes for biogas production-either directly or after pre-processing - and to identify further routes to establish widespread application of this technology to treat biomass from saline soils.

\section{Natural Habitats of Halophytes, Their Role and Adaptive Mechanisms}

\subsection{Natural Habitats of Halophytes}

Salt-tolerant plants or halophytes are plant species that were adapted over a long evolutionary time to thrive and prosper in saline conditions. They are defined as plant species that complete their life-cycle in a salt concentration of at least $200 \mathrm{mM} \mathrm{NaCl}$ [4]. Halophytes occur all over the world in different ecosystems, ranging from pristine alkaline semi-deserts and mangrove forests, through semi-natural meadows and pastures, to manmade habitats. They can be found in irrigated arable lands with poor drainage in the tropics, sand and cliff shorelines in the tropics, salt deserts and semi-deserts, kelp forests and beds, salt marshes, salt lakes and salt steppes, isolated inland saline grasslands and other zones polluted with $\mathrm{NaCl}$ and $\mathrm{CaCl}_{2}$ during deicing [6]. Many of the habitats occupied by terrestrial halophytes are not only saline, but are also prone to flooding, whereas others rarely flood [7]. Further halophyte domestication will lead to establishment of completely new, artificial agro-ecosystems to yield fodder, fiber, food and fuel, and other purposes such as phytoremediation, among others (Table 1 ). Halophytes represent about $2 \%$ of the world angiosperm species. Of the total halophytic species, $57 \%$ come from just 13 families. The Amaranthaceae family (now including the former goosefoot family Chenopodiaceae) has the largest number of halophyte species; over half of its 550 species are salt-tolerant. The families Poaceae, Fabaceae and Asteraceae also include a large number of halophytes, although they represent fewer than $5 \%$ of the species in these families [8]. Salt-tolerant species such as Spartina alterniflora Loisel., Plantago spp., Triglochin spp., Sporobolus viginicus (L.) Kunth, Salicornia spp., Atriplex canescens (Pursh) Nutt., Suaeda maritima (L.) Dumort, 
Batis maritima L., Tripolium pannonicum and Chenopodium quinoa Willd., among many others, have been reported $[8,9]$.

Table 1. Salt-tolerant plant species, origin and uses.

\begin{tabular}{|c|c|c|c|c|c|}
\hline Species & Family & Origin & Uses & $\begin{array}{l}\text { Reported Salt } \\
\text { Tolerance to } \\
\mathrm{NaCl}(\mathrm{mM})\end{array}$ & Reference \\
\hline $\begin{array}{l}\text { Acrostichum } \\
\text { aureum }\end{array}$ & Polypodiaceae & Pantropical & $\begin{array}{l}\text { Ornamental, } \\
\text { medicinal }\end{array}$ & 170 & Kapler [6]; Sun et al. [10] \\
\hline $\begin{array}{l}\text { Althaea } \\
\text { officinalis }\end{array}$ & Malvaceae & $\begin{array}{c}\text { Mediterranean, } \\
\text { invasive in other } \\
\text { regions }\end{array}$ & $\begin{array}{c}\text { Medicinal, } \\
\text { phytoremediator, } \\
\text { ornamental }\end{array}$ & 200 & $\begin{array}{c}\text { Kapler [6]; } \\
\text { Rezaie et al. [11] }\end{array}$ \\
\hline $\begin{array}{l}\text { Ammophila } \\
\text { arenaria }\end{array}$ & Poaceae & $\begin{array}{c}\text { Europe and } \\
\text { western Asia, } \\
\text { uncertain in many } \\
\text { places, invasive }\end{array}$ & $\begin{array}{l}\text { Fodder, biomass, } \\
\text { groundcover }\end{array}$ & $\sim 250$ & Kapler [6]; CABI [12] \\
\hline $\begin{array}{l}\text { Atriplex } \\
\text { hortensis }\end{array}$ & Amaranthaceae & $\begin{array}{l}\text { Cosmopolitan, } \\
\text { uncertain in many } \\
\text { places }\end{array}$ & $\begin{array}{l}\text { Food, fodder, spice, } \\
\text { biofuel }\end{array}$ & $>250$ & $\begin{array}{l}\text { Wilson et al. [13]; } \\
\text { Hasanuzzaman } \\
\text { et al. [14]; Kapler [6] }\end{array}$ \\
\hline $\begin{array}{l}\text { Atriplex } \\
\text { lentiformis }\end{array}$ & Amaranthaceae & $\begin{array}{l}\text { Southwestern USA } \\
\text { and northern } \\
\text { Mexico }\end{array}$ & Food & 500 & $\begin{array}{l}\text { O'Leary et al. [15]; } \\
\text { Hasanuzzaman } \\
\text { et al. [14] }\end{array}$ \\
\hline Batis maritima & Bataceae & America & $\begin{array}{l}\text { Eaten raw, cooked, } \\
\text { or pickled }\end{array}$ & 500 & $\begin{array}{c}\text { O'Leary et al. [15], } \\
\text { Hasanuzzaman } \\
\text { et al. [14] }\end{array}$ \\
\hline $\begin{array}{c}\text { Bruguiera } \\
\text { gymnorrhiza }\end{array}$ & Rhizophoraceae & $\begin{array}{l}\text { Australasia, } \\
\text { Oceania, } \\
\text { East Africa, } \\
\text { Madagascar }\end{array}$ & $\begin{array}{l}\text { Fuel, charcoal, } \\
\text { construction, } \\
\text { medicinal, food, } \\
\text { fodder }\end{array}$ & 500 & Kapler [6]; Zhu et al. [16] \\
\hline $\begin{array}{l}\text { Carpobrotus } \\
\text { spp. }\end{array}$ & Aizoaceae & $\begin{array}{c}\text { South Africa, } \\
\text { south Australian } \\
\text { coast and coastal } \\
\text { Chile }\end{array}$ & $\begin{array}{l}\text { Groundcover, } \\
\text { medicinal }\end{array}$ & $>300$ & Varone et al. [17] \\
\hline $\begin{array}{l}\text { Chenopodium } \\
\text { quinoa }\end{array}$ & Amaranthaceae & Andean highlands & $\begin{array}{l}\text { Cooking, baking, } \\
\text { animal feed, } \\
\text { green fodder and } \\
\text { pellet, modified } \\
\text { food products such } \\
\text { as cereals, } \\
\text { pasta and cookies, } \\
\text { industrial use of } \\
\text { starch, protein and } \\
\text { saponin }\end{array}$ & 400 & Adolf et al. [18] \\
\hline $\begin{array}{l}\text { Cochlearia } \\
\text { danica }\end{array}$ & Brassicaceae & $\begin{array}{l}\text { Atlantic Europe, } \\
\text { now invasive } \\
\text { along motorways } \\
\text { in Eurasia }\end{array}$ & Food, spice & 200 & $\begin{array}{c}\text { Kapler [6]; } \\
\text { Nawaz et al. [19] }\end{array}$ \\
\hline $\begin{array}{l}\text { Cochlearia } \\
\text { officinalis }\end{array}$ & Brassicaceae & Europe & Fresh salads & 100 & $\begin{array}{c}\text { de Vos [20], } \\
\text { Hasanuzzaman } \\
\text { et al. [14] }\end{array}$ \\
\hline $\begin{array}{l}\text { Crambe } \\
\text { maritima }\end{array}$ & Brassicaceae & $\begin{array}{l}\text { Europe from the } \\
\text { north Atlantic } \\
\text { through the } \\
\text { Mediterranean to } \\
\text { Asia and around } \\
\text { the Black Sea }\end{array}$ & Fresh salads & $>100$ & $\begin{array}{l}\text { de Vos et al. [21], } \\
\text { Hasanuzzaman } \\
\text { et al. [14] }\end{array}$ \\
\hline
\end{tabular}


Table 1. Cont.

\begin{tabular}{|c|c|c|c|c|c|}
\hline Species & Family & Origin & Uses & $\begin{array}{l}\text { Reported Salt } \\
\text { Tolerance to } \\
\mathrm{NaCl}(\mathrm{mM})\end{array}$ & Reference \\
\hline $\begin{array}{l}\text { Crithmum } \\
\text { maritimum }\end{array}$ & Apiaceae & $\begin{array}{l}\text { Atlantic Europe, } \\
\text { Mediterranean } \\
\text { regions }\end{array}$ & $\begin{array}{l}\text { Ornamental, food, } \\
\text { edible oil, fodder, } \\
\text { biofuel Fresh and } \\
\text { pickled as spice } \\
\text { and for salads }\end{array}$ & 150 & $\begin{array}{c}\text { Kapler [6]; Ben-Hamed } \\
\text { et al. [22], } \\
\text { Hamed et al. [22]; } \\
\text { Ben Amor et al. [23]; } \\
\text { Hasanuzzaman } \\
\text { et al. [14] }\end{array}$ \\
\hline $\begin{array}{c}\text { Derris } \\
\text { heterophylla }\end{array}$ & Fabaceae & Pantropical & $\begin{array}{l}\text { Medicinal, natural } \\
\text { insecticide and fish } \\
\text { poison for fishing } \\
\text { and } \\
\text { biomanipulation }\end{array}$ & 220 & Kapler [6] \\
\hline $\begin{array}{l}\text { Diplotaxis } \\
\text { tenuifolia }\end{array}$ & Brassicaceae & $\begin{array}{c}\text { Europe, western } \\
\text { Asia and northern } \\
\text { Africa }\end{array}$ & $\begin{array}{l}\text { Mixed salads, } \\
\text { medicinal }\end{array}$ & $\sim 150$ & $\begin{array}{c}\text { de Vos [20]; } \\
\text { Hasanuzzaman } \\
\text { et al. [14] }\end{array}$ \\
\hline $\begin{array}{l}\text { Eugeisonia } \\
\text { insignis }\end{array}$ & Arecaceae & Sarawac' endemic & Food, fodder & & Kapler [6] \\
\hline Glaux maritima & Primulaceae & $\begin{array}{l}\text { Native to Old and } \\
\text { New World }\end{array}$ & Medicinal & 300 & Kapler [6]; Rozema [24] \\
\hline $\begin{array}{c}\text { Inula } \\
\text { crithmoides }\end{array}$ & Asteraceae & $\begin{array}{c}\text { Europe, Africa and } \\
\text { Asia }\end{array}$ & $\begin{array}{l}\text { Salads, pickled in } \\
\text { vinegar }\end{array}$ & $>400$ & $\begin{array}{l}\text { Tardío et al. [25]; Zurayk } \\
\text { and Baalbaki [26]; } \\
\text { Hasanuzzaman } \\
\text { et al. [14] }\end{array}$ \\
\hline $\begin{array}{l}\text { Ipomoea } \\
\text { pes-caprae }\end{array}$ & Convolvulaceae & Pantropical & $\begin{array}{l}\text { Medicinal, fodder, } \\
\text { green manure }\end{array}$ & 300 & $\begin{array}{c}\text { Kapler [6]; } \\
\text { Zhang et al. [27] }\end{array}$ \\
\hline $\begin{array}{l}\text { Limbarda } \\
\text { crithmoides }\end{array}$ & Asteraceae & $\begin{array}{l}\text { Mediterranean, } \\
\text { Black Sea, Atlantic } \\
\text { Europe }\end{array}$ & Food, fodder & 450 & $\begin{array}{c}\text { Kapler [6]; Al-Hassan } \\
\text { et al. [28] }\end{array}$ \\
\hline $\begin{array}{l}\text { Mesembryanthemum } \\
\text { crystallinum }\end{array}$ & Aizoaceae & $\begin{array}{l}\text { North Africa, } \\
\text { south-western } \\
\text { Africa, western } \\
\text { Asia and southern } \\
\text { Europe, invasive in } \\
\text { the New World } \\
\text { and Australia }\end{array}$ & $\begin{array}{l}\text { Ornamental, food, } \\
\text { fodder }\end{array}$ & 400 & $\begin{array}{c}\text { Kapler [6]; Hasanuzza- } \\
\text { man et al. [14]; } \\
\text { Agarie et al. [29]; } \\
\text { Herppich et al. [30] }\end{array}$ \\
\hline Nypa fruticans & Arecaceae & $\begin{array}{l}\text { Australasia, } \\
\text { Oceania }\end{array}$ & $\begin{array}{l}\text { Construction and } \\
\text { fiber material, } \\
\text { source of edible } \\
\text { salt and sugar }\end{array}$ & $>200$ & $\begin{array}{c}\text { Kapler [6]; } \\
\text { Theerawitaya et al. [31] }\end{array}$ \\
\hline $\begin{array}{l}\text { Oncosperma } \\
\text { tigillarium }\end{array}$ & Arecaceae & Australasia & $\begin{array}{l}\text { Prized wood, food, } \\
\text { construction } \\
\text { (traditional spears) }\end{array}$ & $>200$ & Kapler [6] \\
\hline $\begin{array}{c}\text { Pandanus } \\
\text { tectorius, } P \text {. } \\
\text { odoratissimus }\end{array}$ & Pandanaceae & $\begin{array}{l}\text { Australasia, } \\
\text { Oceania }\end{array}$ & $\begin{array}{l}\text { Food, fodder, fiber, } \\
\text { medicinal, } \\
\text { perfume }\end{array}$ & $>200$ & Kapler [6] \\
\hline $\begin{array}{l}\text { Pennisetum } \\
\text { clandestinum } \\
\text { (syn. Sporobolus } \\
\text { virginicus) }\end{array}$ & Poaceae & Pantropical & $\begin{array}{l}\text { Fodder, biomass, } \\
\text { groundcover }\end{array}$ & $>200$ & $\begin{array}{c}\text { Kapler [6]; } \\
\text { Muscolo et al. [32] }\end{array}$ \\
\hline $\begin{array}{l}\text { Phoenix } \\
\text { paludosa }\end{array}$ & Arecaceae & $\begin{array}{c}\text { Australasia, } \\
\text { Oceania }\end{array}$ & Food, fodder & $>200$ & Kapler [6] \\
\hline
\end{tabular}


Table 1. Cont.

\begin{tabular}{|c|c|c|c|c|c|}
\hline Species & Family & Origin & Uses & $\begin{array}{l}\text { Reported Salt } \\
\text { Tolerance to } \\
\mathrm{NaCl}(\mathrm{mM})\end{array}$ & Reference \\
\hline $\begin{array}{l}\text { Plantago } \\
\text { coronopus }\end{array}$ & Plantaginaceae & $\begin{array}{l}\text { Europe, northern } \\
\text { Africa, central and } \\
\text { west Asia }\end{array}$ & Salad, greens & 250 & $\begin{array}{c}\text { Koyro [32]; } \\
\text { Hasanuzzaman } \\
\text { et al. [14] }\end{array}$ \\
\hline $\begin{array}{l}\text { Portulaca } \\
\text { oleracea }\end{array}$ & Portulacaceae & $\begin{array}{l}\text { Native in the Old } \\
\text { and Australasia, } \\
\text { uncertain in the } \\
\text { New World }\end{array}$ & Food, fodder & $<140 \mathrm{mM}$ & $\begin{array}{l}\text { Simopoulos [33]; } \\
\text { Yazici et al. [34]; } \\
\text { Hasanuzzaman } \\
\text { et al. [14]; Kapler [6] }\end{array}$ \\
\hline $\begin{array}{l}\text { Rhizophora } \\
\text { mucronata }\end{array}$ & Rhizophoraceae & $\begin{array}{l}\text { Australasia, } \\
\text { Oceania, } \\
\text { East Africa, } \\
\text { Madagascar }\end{array}$ & $\begin{array}{l}\text { Construction, } \\
\text { especially for } \\
\text { aquaculture, food, } \\
\text { fodder, fuel, } \\
\text { medicine }\end{array}$ & $>500$ & $\begin{array}{c}\text { Kapler [6]; Kodikara } \\
\text { et al. [35] }\end{array}$ \\
\hline $\begin{array}{c}\text { Salicornia } \\
\text { europaea agg. } \\
\text { and Sarcocornia } \\
\text { spp. }\end{array}$ & Amaranthaceae & $\begin{array}{l}\text { S. europaea native } \\
\text { to the Old World, } \\
\text { many species } \\
\text { cosmopolitan }\end{array}$ & $\begin{array}{l}\text { Probiotic, fodder, } \\
\text { biofuel, } \\
\text { phytoremediation, } \\
\text { ornamental }\end{array}$ & 500 & $\begin{array}{l}\text { O'Leary et al. [15]; } \\
\text { Ventura et al. [36]; } \\
\text { Hasanuzzaman } \\
\text { et al. [14]; Kapler [6] }\end{array}$ \\
\hline Salsola kali & Amaranthaceae & $\begin{array}{l}\text { Europe along the } \\
\text { shores of Baltic Sea, } \\
\text { North Sea and the } \\
\text { Atlantic Ocean }\end{array}$ & $\begin{array}{l}\text { Production of } \\
\text { sodium carbonate, } \\
\text { forage }\end{array}$ & $>200$ & Reimann \& Breckle [37] \\
\hline $\begin{array}{c}\text { Sesuvium } \\
\text { portulacastrum }\end{array}$ & Aizoaceae & Pantropical & Food, fodder & 400 & $\begin{array}{c}\text { Kapler [6]; } \\
\text { Messeddi et al. [38] }\end{array}$ \\
\hline Sonneratia alba & Sonneratiaceae & $\begin{array}{l}\text { Australasia, } \\
\text { Oceania, } \\
\text { East Africa }\end{array}$ & $\begin{array}{l}\text { Food, fodder, fuel, } \\
\text { roots used as } \\
\text { buoys }\end{array}$ & $>500$ & Kapler [6] \\
\hline Spinifex spp. & Poaceae & $\begin{array}{l}\text { Australasia, } \\
\text { Oceania }\end{array}$ & Groundcover & & Kapler [6] \\
\hline $\begin{array}{l}\text { Tetragonia } \\
\text { tetragonioides }\end{array}$ & Aizoaceae & $\begin{array}{c}\text { Argentina, } \\
\text { Australia, Chile, } \\
\text { Japan and New } \\
\text { Zealand. }\end{array}$ & Frozen like spinach & 174 & $\begin{array}{l}\text { Wilson et al. [13]; } \\
\text { Słupski et al. [39]; } \\
\text { Hasanuzzaman } \\
\text { et al. [14] }\end{array}$ \\
\hline $\begin{array}{l}\text { Tetragonolobus } \\
\quad \& \text { Lotus }\end{array}$ & Fabaceae & $\begin{array}{l}\text { Native in the Old } \\
\text { World, invasive in } \\
\text { the New World }\end{array}$ & $\begin{array}{c}\text { Fodder, } \\
\text { phytoremediation }\end{array}$ & & Kapler [6] \\
\hline $\begin{array}{l}\text { Triglochin } \\
\text { maritima }\end{array}$ & Juncaginaceae & $\begin{array}{l}\text { Cosmopolitan, } \\
\text { uncertain in many } \\
\text { places }\end{array}$ & $\begin{array}{l}\text { Food, fodder, } \\
\text { biofuel }\end{array}$ & $>250$ & $\begin{array}{l}\text { Kapler [6]; Boestfleisch } \\
\text { \& Papenbrock [40] }\end{array}$ \\
\hline $\begin{array}{l}\text { Tripolium } \\
\text { pannonicum } \\
\text { (syn. Aster } \\
\text { tripolium) }\end{array}$ & Asteraceae & $\begin{array}{l}\text { Eurasia and North } \\
\text { Africa, mostly } \\
\text { Pannon } \\
\text { biogeographic } \\
\text { region and Atlantic } \\
\text { shores }\end{array}$ & $\begin{array}{l}\text { Ornamental, food, } \\
\text { fodder }\end{array}$ & 300 & $\begin{array}{c}\text { Koyro et al. [41]; } \\
\text { Hasanuzzaman } \\
\text { et al. [14]; Kapler [6] }\end{array}$ \\
\hline $\begin{array}{l}\text { Xylocarpus } \\
\text { granatum }\end{array}$ & Meliaceae & Pantropical & $\begin{array}{l}\text { Medicinal, } \\
\text { seed oils used to } \\
\text { make candle, soap, } \\
\text { amadou }\end{array}$ & $\sim 400$ & $\begin{array}{l}\text { Allen et al. [42]; } \\
\text { Kapler [6] }\end{array}$ \\
\hline
\end{tabular}




\subsection{Salt Adaptation Mechanisms}

Salt-tolerant plants are highly evolved and specialized organisms with specific physiological and morphological characteristics, allowing them to grow in saline soils. This remarkable tolerance is complex since it is determined by a number of factors, specific for each particular species [43]. Halophytes can be classified according to their mechanism to tolerate salts, that is, halophytes can be salt excluders having an ultrafiltration mechanism in their root system, salt excreting in which internal salinity levels are regulated via foliar glands and/or salt accumulators that permits the plant to accumulate high salt contents in their cells and tissues and subdue salt toxicity by developing succulence [14]. Some adaptation mechanisms can include blends of, but not limited to, salt exclusion, excretion, succulence, transport and compartmentalization [44]. Salt avoidance involves structural and physiological adaptations to minimize salt concentrations in the cells or physiological exclusion by root membranes [45]. Water potential plays an important role in the halophyte cells, which has to be lower within than outside the plasmalemma to retain cellular water and the necessary osmotic adjustment is achieved mainly by $\mathrm{Na}$ and $\mathrm{C} 1$ ions [46]. $\mathrm{Na}^{+}$and $\mathrm{Cl}^{-}$are largely compartmentalized in vacuoles in halophytic plants [47], which contain $90 \%$ or more of cell water. $\mathrm{Na}^{+}$must be actively pumped into the vacuole from the cytoplasm and it appears to be mediated by $\mathrm{Na}^{+} / \mathrm{H}^{+}$-antiporters in the tonoplast, working together with $\mathrm{H}^{+}$-ATPases and perhaps $\mathrm{PP}_{\mathrm{i}}$ ases, which provide the proton motive force [8]. Nevertheless, excessive ion content in the cytoplasm should be avoided and this is apparently achieved by mechanisms that regulate $\mathrm{K}^{+} / \mathrm{Na}^{+}$selectivity. Some genes may also be involved in salt tolerance in halophytes such as the plasma membrane $\mathrm{H}^{+}$-ATPase gene [48]. The water potential in the cytoplasm of halophytic plants is also adjusted by the accumulation of organic solutes [8]. Some halophytes accumulate proline as a nontoxic and protective osmolyte under saline conditions [49]; additionally, ascorbate, phenols, flavonoids and total antioxidant capacity can be increased under saline conditions [50].

As stated before, ion accumulation is an important adaptation mechanism of several halophytes. According to Flowers and Colmer [4], halophytes have measurably high $\mathrm{Na}^{+}$ intake and transport in order to sustain its water potential gradient and osmotic pressure needed for water intake. Commonly, in salt-tolerant plants, the measurable abundance of ions follows the order $\mathrm{Na}^{+}>\mathrm{K}^{+}>\mathrm{Mg}^{2+}>\mathrm{Ca}^{2+}$ and $\mathrm{Cl}^{-}>\mathrm{SO}_{4}{ }^{2-}$ [44]. These findings were similar to those reported by Akinshina et al. [51], where salt accumulation in dry material varied from $14-49 \%$ in seven different halophytes. In fact, Saliconia europaea agg. contained the largest amounts of mineral compounds mainly $\mathrm{Na}^{+}$and $\mathrm{Cl}^{-}$. It was also observed that the accumulation of salts varied by season.

\section{The Potential Use of Halophytes}

\subsection{Valuable Ingredients and Products of Halophytes}

In addition to the marketable value of the whole plant, halophytes contain important ingredients, such as flavors, fragrances, essential oils, resins, gums, oils, pharmaceuticals and fibers [52,53], that make them even more profitable. Halophytes such as Tripolium pannonicum (Jacq.) Dobrocz, Plantago coronopus L., Lepidium latifolium L. and Salicornia spp. have been reported as having high potential as functional foods or for the supply of nutraceuticals [50]. However, changes in the metabolic profile during exposure to salinity are dependent on the genus, species, cultivar, stress conditions and developmental stage of the plants $[50,54,55]$. Sub-optimal environmental conditions are likely to cause stress in plants, and thus, there is the potential to manipulate metabolic changes through the growing conditions. Boestfleisch et al. [50] pointed out that among the species studied, the halophytes Tripolium pannonicum, Plantago coronopus, Lepidium latifolium and Salicornia europaea demonstrated the most potential as functional foods or nutraceuticals. Other species, such as Tetraena alba (L.f.) Beier \& Thulin (synonym Zygophyllum album), Crithmum maritimum L. and Cakile maritima Scop., have also been reported as potential oilseed halophytes [56].

Seeds of several halophytes contain appreciable quantities of edible oil ranging from $22 \%$ to $25 \%$ [57]. According to Weber et al. [57] the average of the fatty acid composition in 
seed oil of several halophytes was $84 \%$ unsaturated and $16 \%$ saturated, which is a favorable percentage ratio. The oilseed halophyte Salicornia bigelovii Torr., a highly salt-tolerant annual halophyte, yields $2 \mathrm{t} /$ ha of seed containing $28 \%$ oil and $31 \%$ protein, similar to soybean yield and seed quality with unsaturation degree comparable to oils from conventional oil seeds [58]. Seeds of Cakile maritima and Crithmum maritimum are also rich in oil (up to $42 \%$ and $30 \%$ of the seed fresh weight (FW), respectively); similar to olive oil, the fatty acid composition of Crithmum maritimum seeds is characterized by a high level of oleic acid (81\%) [56]. Some studies have shown that some halophytes, when grown in saline environments, can increase the concentration of interesting compounds. For example, Yajun et al. [59] pointed out that the species Descurainaia sophia (L.) Prantl collected from saline soil $(0.4 \% \mathrm{NaCl})$ contained higher amounts of linolenic acid in their seeds as compared to plants originating from non-saline soil $(<0.1 \%$ salt $)(53.7 \%$ and $36 \%$ linolenic acid, respectively). Environmental stresses such as increased salinity often trigger a significant oxidative stress in plants, generating the formation of reactive oxygen species (ROS), which may cause cellular damage. Plants overcome this by enhancing biosynthesis of osmotically active metabolites, specific proteins and antioxidant compounds $[9,53,60]$. In this regard, in many halophytes, a positive correlation among increasing salt concentration in the medium and increasing contents of secondary metabolite production has been observed [9]. For example, Nitaria retusa (Forssk.) Asch showed an increasing phenol and flavonoid contents with increasing salinity ( 0 to $800 \mathrm{mM} \mathrm{NaCl}$ ), whereas the leaf phenol content of Atriplex halimus L. was maximal in presence of $100 \mathrm{mM} \mathrm{NaCl}$ [61]. In addition to their role as antioxidant, polyphenols exhibit a wide spectrum of physiological properties, such as anti-microbial, anti-artherogenic, anti-allergic, anti-thrombotic, anti-inflammatory, cardio-protective and vasodilatory effects [62]. For example, the halophytes Eryngium maritimum L., Crithmum maritimum and Cakile maritima have shown antioxidant and antimicrobial activities [63], which could be used as natural food or cosmetic preservatives. The authors found that Crithmum maritimum exhibited the highest total phenol content and ABTS (2,2'-azinobis (3-ethylbenzothiazoline-6-sulfonic acid)) radical scavenging activity. However, the antioxidant capacity of plants (including total phenols, flavonoids, ascorbate, reduced/oxidized glutathione and reactive oxygen species scavenging enzymes) can be manipulated by altering the saline growing environment, the length of time under saline cultivation and the developmental stage [50]. Besides environmental factors, plant growth stage plays an important role in the concentration of secondary metabolites. Several studies on different halophytic species including Mesembryanthemum crystallinum L., Crithmum maritimum and Limonium densiflorum (Guss.) Kuntze found that the concentration of phenolic compounds and flavonoids is highest in the flowering period [64-66]. For full valorization of halophytes, these valuable ingredients should be separated up-stream by fractionation and extraction processes and subsequent biochemical and thermal conversion processing of halophytes. This can be realized through a biorefinery process design to yield all valuable ingredients. In this set-up, biogas production can be an integrated treatment to exploit the energetic and nutrient value of the residues in a zero-waste regime with recycling of process water.

\subsection{What Makes Halophytes Interesting as a Biomass Resource for Biogas Production?}

Anaerobic digestion (AD) of plant material is generally regarded as a sustainable method to exploit the energetic value of organic matter with simultaneous nutrient recycle when using the digestate as fertilizer. Especially when treating agricultural residues and livestock waste in biogas plants, the reduction of $\mathrm{CO}_{2}$ emissions is two-fold by: (1) producing renewable energy to replace fossil-based energy resources and (2) reducing greenhouse gas (GHG) emissions that are released without AD treatment.

Land and water resources are limited, thereby creating frictions and competition for these limited resources, and raising concerns about food security. Biofuel production, except when based on agricultural residues and waste, requires land; therefore, it competes with other economic and agriculture activities, urbanization and with some environmental 
objectives, especially the protection of biodiversity and carbon sequestration [67]. Currently, the amount of land devoted for growing crops for energy purposes is only $0.19 \%$ of the world's total land area and only $0.5-1.7 \%$ of global agricultural land [68]. With increasing production of energy crops, however, the amount of available land for food crops and the supplied quantity of grains, as is the case of maize, will decrease; therefore, the quantity demanded for basic grains rises, combined with an increase in prices [67]. From a sustainability perspective, the use of crops such as maize for biogas production requires land, and thereby, may be in competition for food and feed production and might lead to indirect land use changes (ILUC) and distortion of food prices, as stated before. Consequently, crop-based biogas production that was established earlier in countries such as Germany for example [68] is no longer supported, and biogas plant operators are looking for new feedstocks with a high biogas yield of which the use is environmentally sound; halophyte plants and their residues could fill this gap.

Based on this, biomass from energy crops is one important factor for biogas production. As mentioned above, land and water are limited resources; consequently, the biomass obtained from energy crops depends in part on land and water availability. Therefore, new cultivation techniques and the use of other potential crops to exploit areas that are not suitable for traditional crops (coastal areas, saline soils) are necessary. Furthermore, due to the perennial life span of many halophytes, it allows harvesting for several years without reseeding while maintaining high biomass production with adequate lignocellulosic properties $[1,69]$. As biogas production is a tailored process to exploit the energetic value of halophytes plants grown on saline soils on the one hand, the range of feedstocks for biogas plants would be broadened.

\section{Cultivation of Halophytes for Biogas Production}

The increased demand and scarcity of food, which inevitably means an increase in food prices, arises partially due to new demands on agriculture for biomass as feedstock in biogas production. Scarcity of these resources is exacerbated as demand increases mainly due to industrial uses, an increase in population and use in the production of biofuels [70]. Besides this, there are other causes that can decrease the availability of these resources such as climate change. This brings us to exploit renewable energy using sustainable systems, and thus, the preservation of resources for future generations is guaranteed. In order to use a sustainable system, avoiding the competition between food crops and energy crops, biomass from halophyte plants has a high potential for biogas production. In this context, marginal land and saline water resources could be used to cultivate plants for biogas production.

The development of $\mathrm{AD}$ of biomass greatly increased as biogas continues to be perceived as a renewable and viable energy source. The feedstock used in conventional technologies were first-generation food crop biofuels derived from starchy grains, wheat and maize, though other sources are also possible. Therefore, to mitigate this food vs. biofuel dilemma, researchers have started to focus on agricultural residues, organic waste and biomass that grows on inedible food or lignocellulosic biomass such as halophytes or non-halophytes to make second-generation biofuels [3]. In addition, the increase in salinization of arable lands and continued depletion of limited freshwater resources is a major constraint for the sustainable production of agriculture as stated above. This vast amount of unused degraded niche saline-affected lands can be used for cultivating feedstocks that can grow under saline conditions [71], which will in turn spare arable lands and waste resources for traditional agriculture. For this reason, halophytes are an ideal candidate for biofuel production due to its ability to grow, reproduce and thrive under high saline conditions, with desirable lignocellulosic composition, mostly perennial and probable rehabilitation of the salt-affected lands.

There are a number of annual and perennial species among halophytes that are able to grow in highly saline environments, such as Chenopodium quinoa, Tripolium pannonicum and Salicornia spp. (Figure 1), among many other species, as described above (Table 1). 


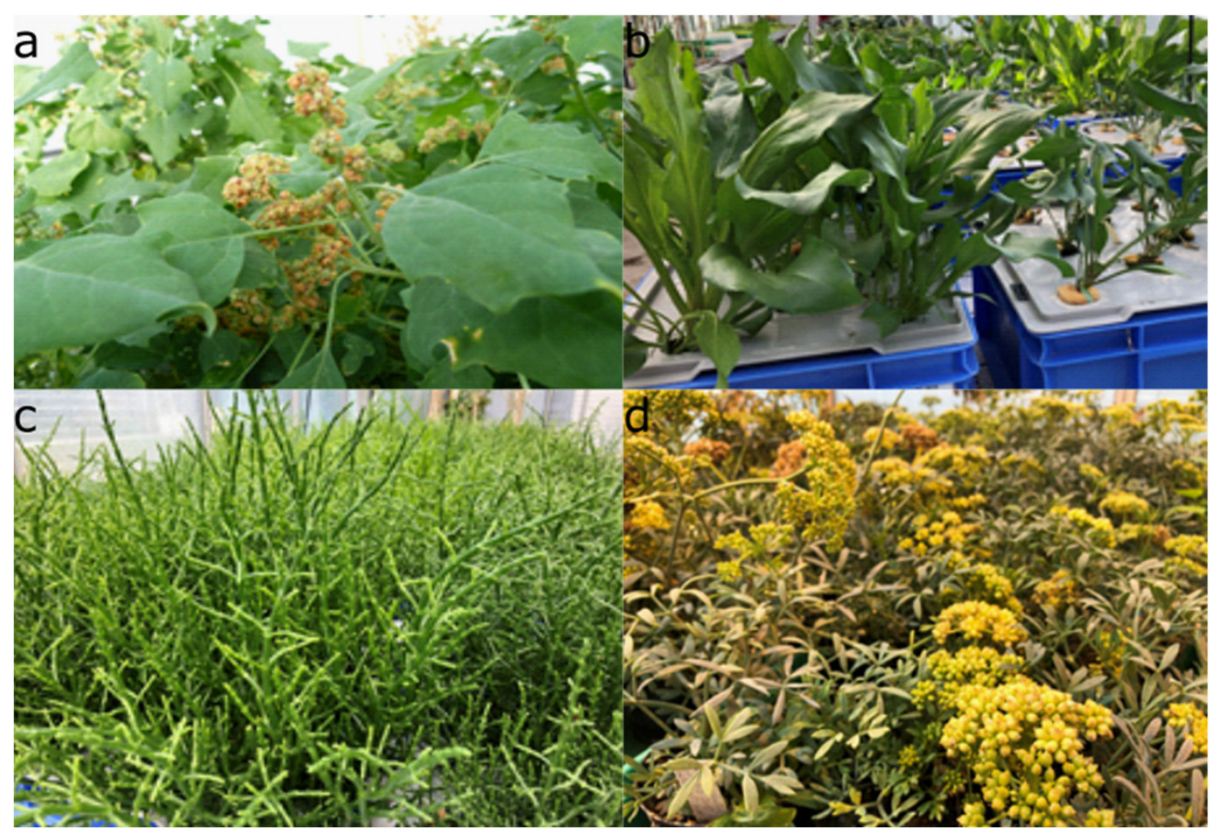

Figure 1. Halophyte plants grown under controlled conditions in hydroponic cultures, (a) Chenopodium quinoa, (b) Tripolium pannonicum, (c) Salicornia europaea and (d) Crithmum maritimum. Source: Own pictures, Ariel Turcios.

These halophytes can also be cultivated in Constructed Wetlands (CWs) to treat wastewater, in hydroponics or in aquaponics [72], and the biomass has a great potential for the production of biogas (Figure 2). It was experimentally shown that some halophytes have a great potential for extracting inorganic contaminants from wastewater, such as nitrates and phosphates [9]. Some other species, such as Tripolium pannonicum and Chenopodium quinoa, among others, have been used for biodegrading xenobiotics in hydroponics and their biomass was used to produce biogas [73,74]. However, for the production of biogas, it is important to take into account the composition of the biomass, which can vary depending on the species, cultivation method and climatic conditions, among others. 


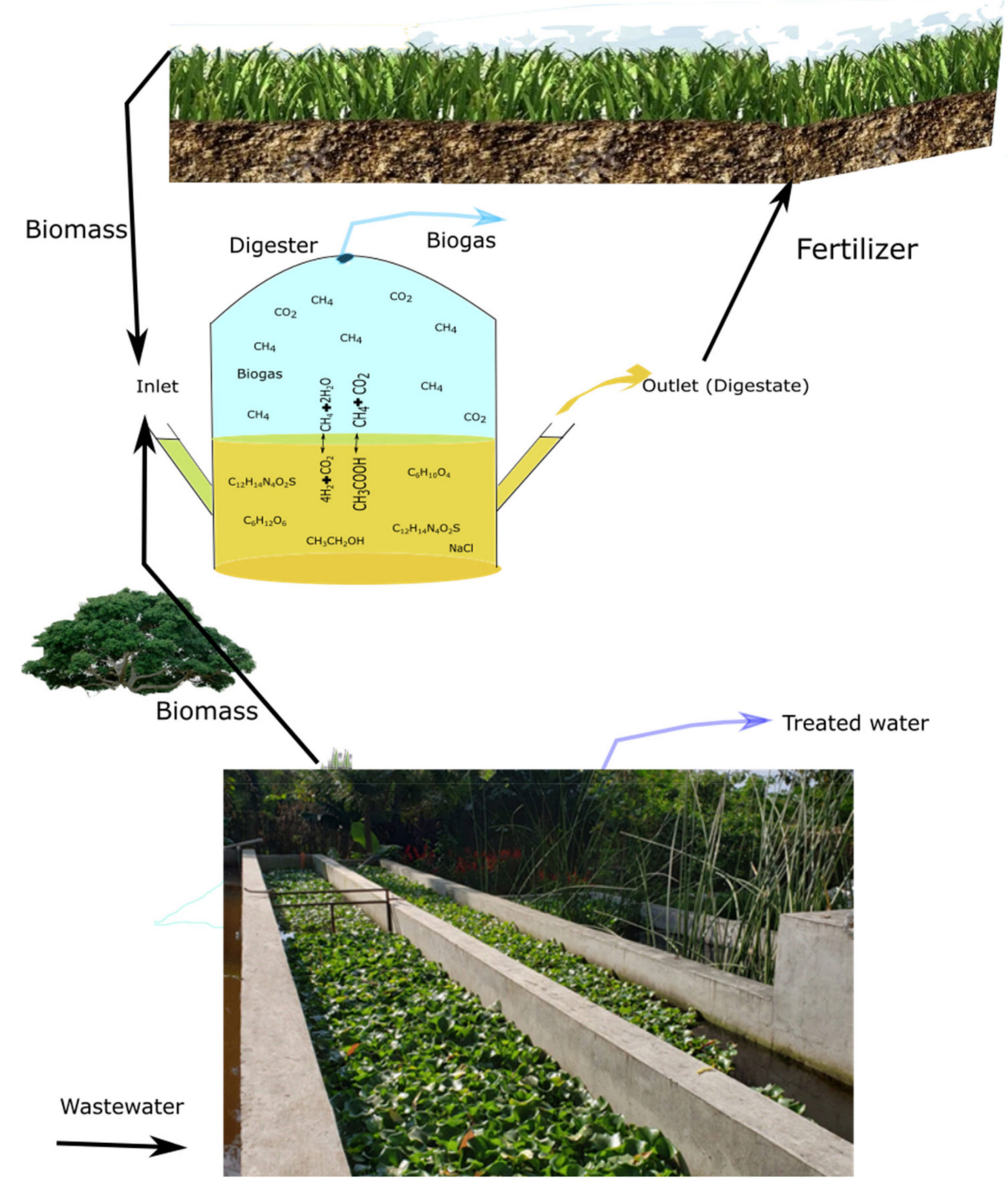

Figure 2. Biofiltration using a constructed wetland and subsequent biogas production system.

\section{Halophyte Composition}

While during evolution halophyte plants adaptive mechanisms were evolved to grow at high salinity levels, the high salt uptake in the plant tissue and salt concentration of the adsorbed water may lead to adverse effects in the processing of halophyte biomass for biofuel production. This can be, for example, by inhibiting the enzymes and microorganisms involved in hydrolysis and fermentation processes and by accelerating the corrosion of process equipment [70]. This way, the accumulation of inorganic salts in the halophyte plants can interfere both thermochemical and biochemical conversion to produce biofuel. Many halophytes collect high salt concentrations in their shoots. As a mechanism to adapt to high saline conditions, some halophyte species store or accumulate excess salt in their tissues or organs, as stated before, while others may develop techniques to exclude salts. Perhaps the halophytic species that discharge salt can be a better alternative as the inorganic content of the biomass produced from accumulators may lead to fouling problems [3]. In addition, the salinity level tends to influence the composition of the organic matter in the plant tissues, i.e., the content and structure of carbohydrates, proteins, lipids and lignin [73]. Moreover, the content of these different organic compounds determines the degradability and the specific biofuel yield of the halophyte biomass in subsequent fermentation processes. Consequently, the composition analysis of halophyte biomass 
is crucial to evaluate the suitability and the potential of a specific halophyte plant for biofuel production. Furthermore, the chemical composition varies significantly with the plant fractions, i.e., stems, pods, seeds and roots. Therefore, a composition analysis of the different plant fractions maybe necessary.

\subsection{Organic Matter Content}

The organic matter or volatile solids (VS) content of halophyte biomass ranges from $51-86 \%$ on dry matter (DM) basis [51,73,74], indicating an up to $49 \%$ high share of minerals and salts in the ash fraction of the DM. The organic matter and ash content, respectively, arethereby influenced by the salt concentration under cultivation of the halophyte plant as analyzed for example for the aboveground biomass of Chenopodium quinoa with a decreasing content when using a growth medium with a higher salinity concentration [74].

\subsection{Ash Content}

Many halophytes can accumulate different quantitative amounts of salts/ions due to their variations in the way the plant utilize salts or rate of uptake/accumulation into the plant tissues or surfaces. Therefore, it is ideal to identify the mineral content of the biomass. According to Akinshina et al. [51], who investigated seven different halophyte biomasses with a conventional grass, they contain $14-49 \%$ mineral content (structural ash) based on the dry matter. Following their findings, Salicornia europaea contained the highest ash content of $49 \%$. It is undeniable that halophytes contain very high concentrations of ash, as contrasted with conventional grass, which contains approximately $5-10 \%$ mineral content in dry material mainly due to their selective uptake of mineral ions as a mechanism of adaptation in saline environments [51,71,73-77]. As reported by Akinshina et al. [75], there were variations in ash content of the investigated wild and cultivated halophyte plants in different seasons of the year. The total ash content is directly proportional to the salinity. This is reflected in findings from Turcios et al. [73] and Turcios et al. [74], where cultivating halophytes under different salinity showed an increase in both crude ash and structural ash content with increasing salinity. As stated in Cybulska et al. [76], a large portion of initial ash content in the raw Salicornia bigelovii plant was in the form of extractable ash, as irrigating the biomass with saline water showed more salt deposits on the plant surface than being incorporated within the plant matrix. Moreover, the stem fractions of Salicornia bigelovii contained less structural ash, $2-8 \%$, as compared to its seed spikes, $5-14 \%$. Conclusively, stems contained less ash both on the surface and incorporated in the plant matrix when compared to pods [76,78].

\subsection{Lignocellulose Content}

Halophyte biomass cultivated from their native environments, inland and coastal salt marshes contained $9-37 \%$ cellulose, $11-39 \%$ hemicellulose and $2-10 \%$ lignin based on the dry matter of the aerial fractions of the plant $[1,79]$. However, the lignocellulosic contents were significantly lower in hydroponically grown halophyte biomass. For instance, on a dry matter basis, Turcios et al. [73] reported the aerial fractions of Tripolium pannonicum grown under 0,15 and $30 \mathrm{~g} \mathrm{~L}^{-1} \mathrm{NaCl}$ contained 6.7, 1.8 and $2.2 \%$ cellulose and 5.7, 8 and $9.5 \%$ hemicellulose, while Turcios et al. [74] reported in dry crop residues of the aerial part of Chenopodium quinoa 16.6, 19.1 and $17.4 \%$ cellulose and 9, 8.9 and $10.1 \%$ hemicellulose in plants cultivated with 0,10 and $20 \mathrm{~g} \mathrm{~L}^{-1} \mathrm{NaCl}$, respectively.

\subsection{Carbohydrate Content}

The content of cellulose, hemicellulose and other sugar polymers in halophyte biomass is typically analyzed by determining the content of monomeric sugars released after acid hydrolysis of the biomass material. While glucose, a C6 sugar, is the only constituent of cellulose, hemicellulose can be composed of C6 and C5 sugars: such as glucose, xylose, arabinose, galactose, mannose and rhamnose. According to Brown et al. [78], the stem fraction of Salicornia bigelovii had a higher carbohydrate content, of $31-56 \%$, compared to 
seed spikes, $16-23 \%$, based on the dry matter content, when cultivated at different fertilizer and salinity levels. In both stem and seed spike fractions, cellulose concentration was higher than hemicellulose. Likewise, seedless Salicornia bigelovii cultivated under $40 \mathrm{~g} \mathrm{~L}^{-1} \mathrm{NaCl}$ and 1-2 $\mathrm{g} \mathrm{N} \mathrm{m}^{-2}$ fertilizer had a carbohydrate content of $19-26 \%$, with cellulose having the highest share, while the carbohydrate concentration in the stem fraction was 32-56\% [76]. Brown et al. [78] showed that cultivating at low salinity $\left(10 \mathrm{~g} \mathrm{~L}^{-1} \mathrm{NaCl}\right)$ and medium fertilizer grade $\left(1.5 \mathrm{~g} \mathrm{~N} \mathrm{~m}^{-2}\right)$ contained highest carbohydrate in stem fractions. Similarly, the dry crop residue of Chenopodium quinoa contained the highest content of carbohydrates when grown under $10 \mathrm{~g} \mathrm{~L}^{-1} \mathrm{NaCl}$ [74] while Turcios et al. [73] reported that the aerial parts of Tripolium pannonicum had the highest carbohydrate content when cultivated under $0 \mathrm{~g} \mathrm{~L}^{-1} \mathrm{NaCl}$.

\subsection{Lignin Content}

The lignin content, determined as the residual part of the lignocellulosic fraction of the halophyte plant after sugar extraction, has generally been found to be notably lower in the aerial fraction of naturally grown halophytes compared to cultivating under controlled conditions of salinity and fertilizer grades [76,78]. For instance, Brown et al. [78] reported a higher Klason lignin content, of $10-17 \%$, in the stems of Salicornia bigelovii as compared to the seed spikes (pods), 5-9\%, when cultivated under different salinity:fertilizer concentration ratios. High salinity was correlated to lower lignin content, particularly in the pod fractions of Salicornia bigelovii. It was observed that stems contained significantly more lignin than pods at higher salinity [76]. Inconsistently, seedlings of Salicornia bigelovii grown under $40 \mathrm{~g} \mathrm{~L}^{-1} \mathrm{NaCl}$ and $1-2 \mathrm{~N} \mathrm{~g} \mathrm{~m}^{-2}$ contained $6.8 \%$ lignin, well within the range of lignin content of naturally grown halophyte biomass [77].

\subsection{Extractives}

Brown et al. [78] and Cybulska et al. [76] studied the extractives from stem and seed spikes of Salicornia bigelovii which were subjected to water extraction followed by ethanol extraction using a Soxhlet apparatus. The composition varied depending on biomass fraction and salinity. According to Cybulska et al. [76], based of dry material, Salicornia bigelovii seed spikes had the highest extractive content, between $54-67 \%$, roughly double the amount contained in stem portions, which was $26-44 \%$. This trend was also similar following the research of Brown et al. [78]. Salinity was found to have a significantly positive influence on extractive contents in both fractions of the Salicornia bigelovii biomass. However, salinity considerably influenced extractive contents that was determined using ethanol extraction, but had no influence on water extractives. On this account, water soluble extractives composition relies solely on biomass fraction, while ethanol extractives content was influenced by both the biomass fraction and salinity [76].

\section{Conversion of Halophytes into Biogas \\ 6.1. The AD Process of Halophytes}

Anaerobic digestion of organic matter involves a sequence of conversion phases that are mediated by consortia of microorganisms that work in synergy in the absence of oxygen to degrade organic macromolecules, to produce methane and carbon dioxide, along with trace quantities of other gases such as hydrogen sulfide. In the initial hydrolysis phase, insoluble complex organic macromolecules such as carbohydrates, protein and fats are hydrolyzed into soluble monomers (sugars, fatty acids and amino acids) by extracellular enzymes excreted by hydrolytic bacteria. In the following acidogenesis stage, the soluble monomers are further broken by acidogenic bacteria into volatile fatty acids (VFA), with acetic acid being the predominant intermediate, as well as carbon dioxide and hydrogen. Other fatty acids are eventually also converted into acetic acid, hydrogen and carbon dioxide. These compounds are finally converted into methane and carbon dioxide by acetoclastic and hydrogen-utilizing methanogens, respectively $[80,81]$. However, the conversion of halophytic biomass into biogas depends on its composition. Therefore, it is 
essential to establish the chemical composition and mineral concentration of the biomass to be used in $\mathrm{AD}$, as it may have an inhibitory effect on due to variation in lignin content and concentration of metals such as $\mathrm{Na}, \mathrm{K}$ and $\mathrm{Mg}$, which can also inhibit microbial activity $[69,79]$. Evidently, the AD of halophyte biomass for biogas production is deemed a profitable process from an economical and environmental perspective. There are copious amounts of benefits using halophyte biomass to produce biogas in arid saline-affected lands; for instance, no competition for land or fresh water uses in these regions and low resource costs. Although halophytes can be converted to safe energy by AD, there exist some unfavorable factors which can affect biogas production.

\subsection{The Biogas Potential of Halophytes}

The AD process is well-established for the conversion of agricultural residues, food waste, animal slurry and other organic waste into biogas, which can be directly used as renewable fuel for combined heat and power (CHP) generation or-as biomethane after upgrading-be injected into the natural gas grid. Generally, biogas/biomethane yields are expressed in terms of $\mathrm{mL} \mathrm{g}^{-1}$ volatile solids (VS), which reflects the yield of biogas/biomethane per $g$ of VS, the organic matter fraction of total solids (TS) that can be maximally degraded. Numerous biomass species and biomass residues have been evaluated and proved feasible for their biogas/biomethane production, such as, clover, cereals, maize and sunflower, though other sources are also possible. However, there is limited research on the biogas production potential of halophytic biomass. In principle, it would be an advantageous source of feedstock for biogas production in saline arid lands, as these plants are able to optimally thrive in high-salt conditions and absorb substantial quantities of salt, and thus, provide an avenue for the remediation of saline lands. In fact, salt-tolerant plants will not contend with traditional crops for land and water reserves in those regions.

Yang et al. [79] produced biogas at a yield of $358 \mathrm{~mL} \mathrm{~g}^{-1}$ of organic solids or volatile solids (VS) with aboveground biomass of Spartina alterniflora through AD $\left(60 \mathrm{~d}, 35{ }^{\circ} \mathrm{C}\right.$ and $1 \mathrm{~atm})$. However, based on the elemental composition of Spartina alterniflora, the theoretical biogas yield was calculated at $795 \mathrm{~mL} \mathrm{~g}^{-1} \mathrm{VS}$. Hence, based on this theoretical value, only $45 \%$ biodegradability was achieved from the AD experiment. It was suggested that upon analysis of cations, the sustained concentrations of $\mathrm{K}^{+}$and $\mathrm{Mg}^{2+}$ ions may have caused inhibitory effects during AD. Spartina alterniflora was also found to contain a high lignocellulosic content: 10\% lignin, 30\% hemicellulose and 34\% cellulose on a dry basis $[79,82]$. Therefore, the hydrolysis of the lignocellulosic material content, which accounts for about $74 \%$ of the gross quantity, can be viewed as the rate-limiting step in the AD processes of this halophyte.

Similarly, Chen et al. [82] investigated the biogas yield of Spartina alterniflora, sampled from the same region as Yang et al. [79], but in a later season under varying organic loadings of the batch reactors. Biogas yields of 290 and $299 \mathrm{~mL} \mathrm{~g}^{-1} \mathrm{VS}$ were achieved at an initial loading of $4 \% \mathrm{VS}$ and $6 \% \mathrm{VS}$, respectively, while the yield decreased to $253 \mathrm{~mL} \mathrm{~g}^{-1} \mathrm{VS}$ at a loading of $8 \%$ VS. The lower biogas yields of Spartina alterniflora compared to $358 \mathrm{~mL} \mathrm{~g}^{-1}$ VS found by Yang et al. [79] are presumably due to the maturity of the halophyte plant with a lower content of easily degradable organic matter.

The assessment of biogas potential from AD of wild or cultivated halophytes plants were investigated by Akinshina et al. [75] in a series of batch-test and continuous mode experiments. The highest biogas yields from the investigated halophyte plants were from Suaeda paradoxa (Bunge) Bunge, Atriplex saggitata (Borkh) and Karelinia caspia (Pall.), with values of $277-398 \mathrm{~mL} \mathrm{~g}^{-1} \mathrm{DM}, 291-366 \mathrm{~mL} \mathrm{~g}^{-1} \mathrm{DM}$ and 257-358 $\mathrm{mL} \mathrm{g}^{-1} \mathrm{DM}$, respectively, under mesophilic conditions. These species contained, on a dry matter basis, about $736 \mathrm{mg} \mathrm{g}^{-1} \mathrm{VS}, 765 \mathrm{mg} \mathrm{g}^{-1} \mathrm{VS}$ and $795 \mathrm{mg} \mathrm{g}^{-1} \mathrm{VS}$, respectively, which were the highest organic fractions observed, and also contained the least amounts of mineral ions accumulated in their biomass. It was anticipated within this study that the halophyte with the highest biomass yield, Salicornia europaea agg., will exhibit the highest biogas 
yield, but in reality, it demonstrated the lowest biogas yield. High sodium and sulfate content present in the halophyte species investigated caused drawbacks in the production of biogas. Likewise, according to Akinshina et al. [71], the variation in the anaerobic degradation of halophytic biomasses are related to variations in the concentration of nutrients and some chemical compounds that are deemed inhibitory for AD. Furthermore, the differences in anaerobic decomposition can also relate to the variation in lignin content and due to its recalcitrant nature, which is considered to be non-degradable in anaerobic conditions $[71,83]$.

The biogas and methane potential of different halophyte species grown under hydroponic conditions using different concentrations of $\mathrm{NaCl}$ and artificial seawater were also investigated under AD [73,74]. The halophyte, Tripolium pannonicum, achieved the highest specific biogas yield grown under non-saline conditions of $476 \mathrm{~mL} \mathrm{~g}^{-1} \mathrm{VS}$, whereas the highest specific methane yield was obtained from plants grown under $15 \mathrm{~g} \mathrm{~L}^{-1}$ and $22.5 \mathrm{~g} \mathrm{~L}^{-1}$ sea salt of $309 \mathrm{~mL} \mathrm{~g}^{-1}$ VS and $313 \mathrm{~mL} \mathrm{~g}^{-1}$ VS. Tripolium pannonicum obtained higher specific biogas and methane yield grown with $30 \mathrm{~g} \mathrm{~L}^{-1}$, with an average of $554 \mathrm{~mL} \mathrm{~g}^{-1}$ VS and $347 \mathrm{~mL} \mathrm{~g}^{-1}$ VS, respectively [73]. Similarly, Chenopodium quinoa was cultivated with varying concentrations of $\mathrm{NaCl}$ and evaluated for specific biogas and methane yield on a fresh biomass and dry material basis. Based on fresh biomass, the highest specific biogas and methane yield was achieved with plants grown at $20 \mathrm{~g} \mathrm{~L}^{-1}$ $\mathrm{NaCl}$ with $470 \mathrm{~mL} \mathrm{~g}^{-1} \mathrm{VS}$ and $305 \mathrm{~mL} \mathrm{~g}^{-1} \mathrm{VS}$, respectively. Likewise, based on dry matter, cultivation with $20 \mathrm{~g} \mathrm{~L}^{-1} \mathrm{NaCl}$ obtained both the highest specific biogas yield of $459 \mathrm{~mL} \mathrm{~g}^{-1}$ VS and methane yield of $289 \mathrm{~mL} \mathrm{~g}^{-1}$ VS [74]. The biogas yields from this halophytic species are higher in comparison with many other conventional crops, which show the favorability of using of this halophyte species for biogas production. For instance, Scarlat et al. [84] reported an average specific methane yield of $250-450 \mathrm{~mL} \mathrm{~g}^{-1} \mathrm{VS}$ from maize silage, 200-250 mL g ${ }^{-1}$ VS from straw, 300-450 $\mathrm{mL} \mathrm{g}^{-1}$ VS grass and $230-380 \mathrm{~mL} \mathrm{~g}^{-1}$ VS from sugar beet. In the same direction, Amon et al. [85] reported an average specific methane yield of $398 \mathrm{~mL} \mathrm{~g}^{-1}$ VS from maize, $140-343 \mathrm{~mL} \mathrm{~g}^{-1}$ VS from wheat, $128-392 \mathrm{~mL} \mathrm{~g}^{-1} \mathrm{VS}$ from different grasslands and $428-454 \mathrm{~mL} \mathrm{~g}^{-1}$ VS from sunflowers in the first harvest. In essence, based on specific biogas/methane yields in conjunction with desirable cellulose/hemicellulose and low lignin content, halophytic biomass is an optimal candidate for energy exploitation (Figure 3). 


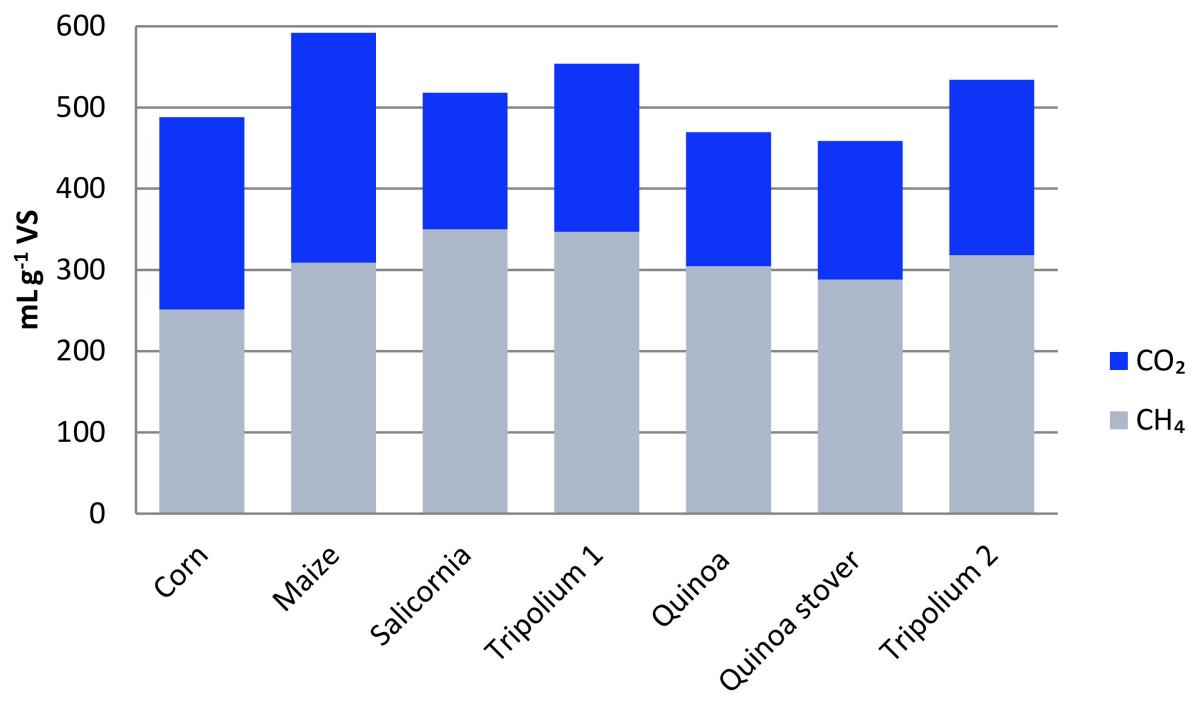

Substrate

Figure 3. Biogas production using different plant biomass cultivated under different conditions. Corn: green corn stover [86]; Maize: green maize for ensiling [86]; Salicornia: fresh biomass of Salicornia europaea cultivated in hydroponics with $10 \mathrm{~g} \mathrm{~L}^{-1} \mathrm{NaCl}$ [87]; Tripolium 1: fresh biomass of Tripolium pannonicum cultivated in hydroponics with $30 \mathrm{~g} \mathrm{~L}^{-1} \mathrm{NaCl}$ [73]; Quinoa: fresh biomass of Chenopodium quinoa cultivated in hydroponics with $20 \mathrm{~g} \mathrm{~L}^{-1} \mathrm{NaCl}$ [74]; Quinoa stover: stover of Chenopodium quinoa cultivated with $20 \mathrm{~g} \mathrm{~L}^{-1} \mathrm{NaCl}$ [74]; Tripolium 2: fresh biomass of Tripolium pannonicum cultivated in hydroponics with $5 \mathrm{mg} \mathrm{L}^{-1}$ sulfadimidine [88].

\subsection{Inhibiting Effects of Halophytes on the AD Process}

The efficiency of the AD process is steered by many pivotal parameters. Hence, it is essential to provide suitable conditions for anaerobes. Growth and activity of anaerobe microorganisms is considerably affected by parameters such as $\mathrm{pH}$ value, absence of oxygen, constant temperature, $\mathrm{C} / \mathrm{N}$ ratio, ammonia, macro- and micronutrients and toxic compounds [81]. Particularly, the acid-producing bacteria and methanogens in the anaerobic digestion pathway vary significantly with respect to nutritional requirements, growth kinetics, physiology and sensitivity to environmental conditions. Inability to preserve the balance amongst these two groups of anaerobic microorganisms is the principal source of instability in reactors [89]. An array of inorganic and organic substances has been reported to be inhibitory or toxic in the process of AD. A substance could be deemed toxic when it creates an unfavorable shift in the population of microorganisms or inhibition of the growth of the microorganism. This is usually identified by a reduction of the steady-state rate of $\mathrm{CH}_{4}$ yield and organic acid accumulation [89].

The application of the $\mathrm{AD}$ process to saline biomass will broaden the industrial use of halophytes for biofuel production. The AD of halophytic biomass has many challenges that demands attention before the integration of this process can be valorized in the halophyte industry. One unambiguous challenge encountered in the AD of halophytic biomass is the associated high salinity within the cells and tissues of the biomass.

The effects of salinity on AD are clearly established [89-91]; it is indicated that for sodium, which is considered the main inhibiting element of the light earth metals, with a concentration ranging between 3.5-5.5 $\mathrm{g} \mathrm{L}^{-1}$, AD can moderately inhibit methanogen microorganisms. McCarty [91] later investigated this inhibitory concentration of sodium and suggested an increase to $8.0 \mathrm{~g} \mathrm{~L}^{-1} \mathrm{Na}$ can cause a strong inhibitory effect on the methanogenic bacteria at mesophilic conditions. In light of their findings [92], the light earth metals are required in very minimal concentrations for the metabolism in bacterial cells, and on the other hand, above optimal concentrations, they can be severely toxic to methanogenic bacteria. Many researchers studied the effects of the cations $\mathrm{Na}^{+}, \mathrm{K}^{+}, \mathrm{Ca}^{2+}$, $\mathrm{Mg}^{2+}$ and $\mathrm{NH}_{4}[92,93]$. These early research findings indicated the monovalent cations 
were more toxic or the same in toxicity to divalent cations based on molarity. Furthermore, according to their results, the inhibition on biogas production due to sodium concentration depends of the antagonistic/synergistic effects between elements. Consequently, it is essential to establish the elemental content of the halophytic substrates and to analyze its effect on biogas/biomethane yield. According to several studies, increasing sodium concentration may have caused a decrease in specific biogas and biomethane yields $[69,73,74,94]$. Nevertheless, it is uncertain whether or not this is solely due to the sodium concentration levels in the anaerobic reactor or an accumulation of other metal elements or organic compounds. It has been highlighted by many researchers that a higher concentration of sodium causes a dehydration of microbial cells or, to a greater extent, death, due to the increase in osmotic pressure, which would further bring about inhibition and even failure during the processes of AD [89,95-97]. In consideration of the aforementioned facts, it is paramount to study the effects of high concentration of salts on biogas/biomethane production during AD.

\subsubsection{Optimization of AD Microorganism Composition}

As previously mentioned, the AD process encompasses a sequence of phases, in particular, hydrolysis, acidogenesis, acetogenesis and methanogenesis. Notably, these different phases within this codependent conversion pathway are executed by the presence and activity of an intricate consortia of microbial bacteria facilitating to an efficient degradation of organic material. The bacterial activity that led the first three phases converts organic material into VFAs and further digested into acetate, $\mathrm{H}_{2}$ and $\mathrm{CO}_{2}$. The fourth phase is performed by the archaeal community, which utilizes the products from the acidogenic stage to produce $\mathrm{CH}_{4}$ [97]. The overall conversion of organic material into methane demands a synergistic activity amongst the microbial community.

Acid- and methane-forming bacteria vary considerably with respect to their nutritional requirements, rate of growth kinetics, physiology and responsiveness to environmental plasticity. Thus, the inability to sustain a degree of equilibrium between both bacterial communities is the main source of anaerobic reactor instability [89]. More specifically, according to the findings of Ward et al. [96], the methanogenic microorganisms are significantly influenced by the variations in environmental conditions in comparison to the acidogenesis and hydrolysis phases of AD. For this reason, it is crucial to completely fathom the behavioral characteristics of the microorganisms to primarily improve the efficiency of the processes involved in anaerobic degradation.

Halophytic biomass contains high amounts of minerals due to the physiological adaptation mechanisms by accumulating salt within their cells and tissues to optimally develop under high saline conditions. At high concentrations, these minerals can affect the behavioral activity of the microbial bacteria in the AD process; nevertheless, low mineral salt content is necessary for microbial growth and reproduction. It is essential, in the case of $\mathrm{AD}$ technologies, to create a process that can effectively operate at high salt concentration. Halophilic and/or halotolerant anaerobic microorganisms are basic to achieve this. On that account, it is integral to explore the behavior of the bacteria and archaea associated with the biogas/biomethane production from halophytic biomass at different concentrations of salinity.

Several approaches were established to enhance the performance of AD at high salt conditions, for instance, the use of osmoprotectants [98], halotolerant bacteria [99] and an extended time for halophobic inocula to adjust to saline condition [100]. According to the findings of Yerkes [95] and Zhang et al. [101], when treating raw materials with a high salt content, inoculum acclimatization is more effective over a relatively long period of time. Wang et al. [97] suggested that increasing the concentration of $\mathrm{NaCl}$ from 0 to $20 \mathrm{~g} \mathrm{~L}^{-1}$ did not adversely affect the hydrolytic and acidogenic activity of bacteria, but rather promoted it, while on the other hand, the methanogenic activity of the archaeal community, in methanogenesis, was strongly inhibited. Additionally, it was stated that a significant shift in bacterial community was observed between $20 \mathrm{~g} \mathrm{~L}^{-1}$ and $0 \mathrm{~g} \mathrm{~L}^{-1} \mathrm{NaCl}$, in that a variety 
of halotolerant bacteria was able to acclimatize to the saline conditions. The experiments of Mottet et al. [102] showed similar methane production efficiencies between inoculum from a WTP (non-saline conditions) and halophilic inoculum from saline sediments tested to $35 \mathrm{~g} \mathrm{~L}^{-1}$ salinity. However, at higher salinity methanogenesis was significantly reduced. The findings reported by Ward et al. [103] indicate that testing to develop inoculum influenced the methanogens into an acclimatization period, where, as a result, they became more tolerant to saline environments and perhaps favor increased saline conditions. These findings were in alignment with those of Omil et al. [104], Feijoo et al. [105] and Lefebvre et al. [106], who disclosed that the potential for the methanogenic group to acclimatize in order to tolerate higher saline conditions is dependent on the bacterial community. Buxy et al. [107] and Turcios et al. [73] also validated these results; they were able to achieve higher gas production under saline conditions after operating the test one more time.

The performance and kinetics of biogas/biomethane production in AD affected by salt content was studied by different researchers $[73,74,94]$ by utilizing the modified Gompertz equation model to statistically describe the growth of the microbial community by fitting the cumulative biogas/biomethane production at a specified digestion time, the ultimate biogas/biomethane production, the maximum biogas/biomethane production rate per day, the lag phase period or minimum time needed to produce biogas/biomethane and the exponential phase. According to Zhang et al. [94], with increasing sodium concentration, the ultimate methane production and maximum methane production rate were slightly increased from $0.49-4.42 \mathrm{~g} \mathrm{~L}^{-1} \mathrm{Na}$ and then decreased progressively from 4.42-24.08 $\mathrm{g} \mathrm{L}^{-1} \mathrm{Na}$ concentration, as well as gradual increase in lag phase period up to $16.22 \mathrm{~g} \mathrm{~L}^{-1} \mathrm{Na}$ content. Thus, this implies that the methane production kinetics is considerably affected by sodium content. This is dissimilar to the findings of Turcios et al. [73,74], who reported no notable difference between the kinetic biogas yield rates of salt-optimized inoculum with added salt of $6.3 \mathrm{~g} \mathrm{~L}^{-1} \mathrm{NaCl}$. This is similar to the results reported by Mottet et al. [102], whose findings suggested that optimized inoculum could effectively convert saline substate into biomethane at $4.6 \mathrm{~g} \mathrm{~L}^{-1} \mathrm{Na}$ content. This may be due to the increase in salt-acclimatized microbes that evolved adaptation mechanisms and tolerance to saline environments. Conclusively, the potential for $\mathrm{AD}$ microbial communities to acclimatize to environmental variations through progressive optimization in composition and metabolism to environmental changes could propose a favorable approach to improve bacterial metabolism and optimize the microbial community to operate at higher saline concentrations in the AD process. It is with great anticipation that this halotolerant $\mathrm{AD}$ bacterial community has the potential to be further advanced and be a significant factor in narrowing the gap in the nutrient cycle related to the production of halophytic biomass-based biofuel production technologies.

\subsubsection{Co-Digestion of Halophytes}

The method of choice to overcome adverse properties of certain biomass feedstocks for $\mathrm{AD}$, i.e., $\mathrm{C} / \mathrm{N}$ ratio, $\mathrm{pH}$, moisture content, the concentration of nutrients, trace metals and toxic compounds, is to co-digest different biomass feedstocks with synergistic characteristics $[82,96,108,109]$. The $\mathrm{C} / \mathrm{N}$ ratio is one of the most important process parameters for $\mathrm{AD}$, which can be adjusted through co-digestion of different feedstocks to an optimum range between 10-30 [85]. Low $\mathrm{C} / \mathrm{N}$ ratios of biomass leads to a relatively high release of ammonia during decomposition, which will eventually inhibit methanogenic archaea, leading to a decrease in methane production and an accumulation of VFAs within the anaerobic reactor. On the other hand, a high $\mathrm{C} / \mathrm{N}$ ratio can cause nitrogen deficiency in the whole anaerobic microbial consortium, thus decreasing the methane production potential $[74,96,110]$. Many studies indicate that low $\mathrm{C} / \mathrm{N}$ ratios were overcome through co-fermentation of microalgae with other waste streams or biomass, such as pig manure, cow manure, corn stalks, municipal wastewater solids and lipid-rich fats, oils and grease, though other sources are also possible. The utilization of two substrates in co-digestion showed a significant increase in methane yield and a more balanced $\mathrm{C} / \mathrm{N}$ and VFA/alkalinity ratios compared to mono- 
substrate digestion. For example, Mshandete et al. [111] investigated the co-fermentation of fish waste and sisal pulp and stated that an anaerobic co-digestion of $67 \%$ sisal pulp and $33 \%$ fish waste showed an increase in methane yield of $59-94 \%$ in comparison to mono-substrate digestion.

Some research has been performed on halophyte biomass used as mono substrate, but little on co-substrates, and this may vary the $\mathrm{C} / \mathrm{N}$ ratio. For example, the research by Ward et al. [96] and Turcios et al. [74] showed a C/N ratio of less than 10 for mono-substrate $\mathrm{AD}$ of halophilic microalgae and halophyte Chenopodium quinoa, respectively. Low $\mathrm{C} / \mathrm{N}$ ratios of biomass can lead to a relatively high release of ammonia during decomposition, as explained above. Many studies indicate that low $\mathrm{C} / \mathrm{N}$ ratios were overcome by cofermentation of microalgae with other waste streams or biomass, such as cow manure, corn stalks, wastewater sludge and lipid-rich waste such as fats, oils and grease. The utilization of two substrates in co-digestion showed a significant increase in methane yield and a more balanced $\mathrm{C} / \mathrm{N}$ and VFA/alkalinity ratios compared to mono-substrate digestion. However, there is still limited research on the anaerobic co-digestion of halophytic biomass with biodegradable materials to enhance biogas/biomethane production. As previously mentioned, halophytes are able to accumulate high salt contents in their tissues without affecting drastically their biomass production, but they are capable of decreasing the rate of digestion of biomass substrate to produce biofuel by hindering the enzymatic degradation of lignocellulose and accelerating the corrosion of reactor components [112]. One approach to overcome such undesirable consequences is co-digestion with biodegradable substrates that act as energy supplies. Chen et al. [82] investigated the co-digestion of the halophyte Spartina alterniflora with varying co-digestion ratios of cow manure at an organic loading of $7 \%$ VS. With the addition of cow manure, the $\mathrm{C} / \mathrm{N}$ ratio dropped from 21.82 to 14.19, of which the optimum range is between 10-30 [85], and co-digestion improved the biodegradation of Spartina alterniflora, with lower VFAs concentrations and higher methane yields of 7 to $44 \%$. Yang et al. [113] also investigated the lignocellulosic structural changes of Spartina alterniflora after anaerobic co-digestion with potato, and reported that co-digestion had more favorable effects on improving the hemicellulose degradation in comparison to mono-substrate digestion. Oh et al. [98] suggested that the addition of osmoprotectants, glycine betaine, offers an effective alternative for co-digestion to minimize the toxic/inhibitory effects caused by high salinity. Ultimately, AD of halophytes can be significantly improved by adjusting the co-digestion ratio of halophytic biomass with other biomass or waste streams under varying salinity concentrations to an optimum with high biogas / biomethane yields and process stability. Thereby, co-digestion of halophytes, together with other biomass, can offer a solution to the unfavorable conditions in mono-substrate digestion, and halophytes can become a welcome feedstock to boost biogas production in existing large scale biogas plants.

\section{Full-Scale Application of Biogas Production from Halophytes}

For more than 20 years, anaerobic digestion has become a mature full-scale technology for the treatment of agricultural residues and livestock waste, energy crops and municipal and industrial organic waste and wastewaters. Depending on feedstock availability and economic frameworks, full-scale application of AD can be very versatile, from high-tech large-scale centralized plants to farm-scale plants and low-tech plants on a household scale. Depending on the feedstock characteristics, full-scale technology can generally be distinguished into three different systems:

- CSTR (continuous stirred tank reactor) systems for the treatment of slurries, such as manure or sewage sludge, with an optional admixing of other solid organic substrates;

- Dry AD systems for mono digestion of solid biomass or organic waste, such as OFMSW (organic fraction of municipal solid waste), with a total solids (TS) content of more than $15 \%$;

- High-rate reactor systems of the UASB (up-flow anaerobic sludge bed) or EGSB (expanded granular sludge bed) type for the anaerobic treatment of wastewater. 
Accordingly, biogas production from halophytes can be applied in full scale with different sizes and different technology levels using AD technology suited for the treatment of solid biomass, i.e., CSTR systems for co-digestion of halophyte material together with other liquid biomass or as mono digestion in dry AD systems [114-116].

Co-digestion of halophytes in CSTR systems has the advantage of direct dilution of the salt concentration through the addition of the liquid waste, thereby reducing inhibition effects, but this requires the availability of at least twice the amount of liquid organic waste streams in the proximity of the plant to reduce the TS concentration of the feed mixture to $\max 15 \%$ to enable mixing and pumping.

Mono digestion, on the other hand, can be directly applied on-site, where the halophyte biomass or plant residues are produced, reducing the need of transportation of other biomass feedstocks. However, in this case, measures must be taken to reduce the salt concentration prior to feeding to the biogas reactor to avoid inhibiting effects in the $\mathrm{AD}$ process. This could be implemented by combining percolation of the biomass for dissolving the salt in the percolate and subsequent salt removal from the percolate before its recirculation on the biomass. This requires advanced separation techniques, for example membrane filtration and a subsequent treatment of the salt effluent [117].

Process efficiency wise, higher specific methane yields were generally achieved for co-digestion of solid organic waste in wet digestion systems at organic loading rates (OLR) below $6 \mathrm{~kg}-\mathrm{VS} \mathrm{m}^{-3} \mathrm{~d}^{-1}$, while dry mono-digestion systems showed to be favorable at higher OLR [117]. Consequently, the decision of co-digestion vs. mono-digestion for large-scale applications rather depends on the availability of liquid biomass streams in the proximity of the biogas plant treating halophyte biomass. Simply speaking, codigestion of halophytes is the first choice if other biomass is available; otherwise, mono digestion can be applied, but this needs the integration of solid/liquid separation and desalination processes.

\section{The Biogas Process as Part of a Biorefinery for Conversion of Halophyte Biomass}

In case that mono-digestion of the halophyte plant is the process of choice, then a biorefinery approach with extracting high-value compounds of the halophytes first and converting the residues into other valuable products would give the highest economic benefit and exploit the full value of halophyte plants. In this case, anaerobic digestion is the most suitable option to convert the residual streams of non-converted sugars, proteins and lipids into biogas/biomethane for final energy recovery, while recovering the nutrients in the digestate to be used as fertilizer. Here, anaerobic digestion is the tailored process, since the residual streams have a high moisture content and the different residual organic compounds can be converted in a single process.

These benefits have been shown earlier when implementing $\mathrm{AD}$ as the final stage of biorefinery systems, e.g., of cellulosic ethanol biorefineries, green biorefineries or biodiesel biorefineries [118-120]. The biorefinery approach for the conversion of halophyte biomass with AD implemented as the conversion of the residual organic matter would, on the other hand, imply the advantage that the salt concentration in the residual stream would be lowered compared to the original plant material through the different up-stream extraction processes applied. Consequently, the integration of AD in a biorefinery concept for halophyte conversion would give the highest overall valorization of the halophytes and would make the AD process most feasible for the treatment of halophyte biomass.

Figure 4 summarizes the different factors influencing the $\mathrm{AD}$ of halophyte biomass. 

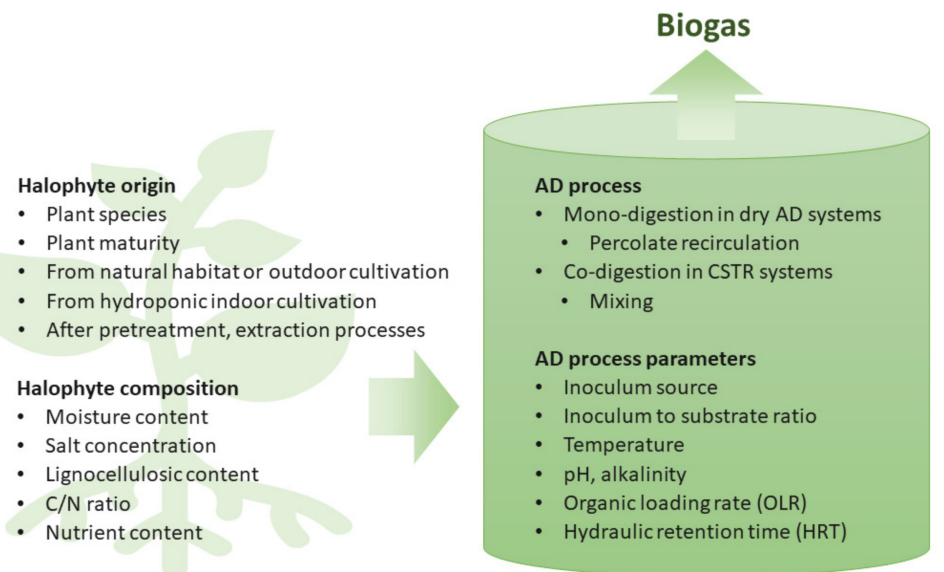

Figure 4. Factors affecting the anaerobic digestion (AD) of halophyte biomass. CSTR, continuous stirred tank reactor.

\section{Conclusions}

Halophytes have great potential to serve as cultivated crop in saline areas where conventional crops cannot grow. Anaerobic digestion of halophyte plants or their residues is, hereby, a versatile process to exploit the energetic value of the plant as biomethane and recovering nutrients in the digestate for fertilizer use. However, optimization of the AD process and integration of additional processes may be necessary, since the plant material contains considerable amounts of salt that can affect the digestion process. Co-digestion with other biomass feedstocks and the use of salt-tolerant anaerobic microorganisms are, hereby, the first choice to overcome the adverse effect of salinity. In addition, to exploit the full value of halophyte plants, anaerobic digestion can be an integrated process of biorefining of the plant material after extracting valuable compounds such as oils, essential fatty acids and several secondary metabolites. Hereby, the value of halophyte plants could switch from a phytoremediator of saline soils only, to a valuable crop for production of food, food ingredients and fuel. From a process point of view, the up-stream extraction processes in the biorefinery approach would leave the residues at lower salt concentration that can be directly used for biogas production.

Author Contributions: Conceptualization, J.P., A.E.T. and H.U.; writing-original draft preparation, J.P., H.U., A.C. and A.E.T.; writing-review and editing, J.P., H.U., A.C. and A.E.T.; visualization, J.P. and A.E.T.; supervision, J.P. and H.U.; project administration, J.P. and H.U. All authors have read and agreed to the published version of the manuscript.

Funding: This research received no external funding.

Institutional Review Board Statement: Not applicable.

Informed Consent Statement: Not applicable.

Data Availability Statement: Data sharing not applicable.

Acknowledgments: Current collaboration is funded by the EU project Aquacombine (Grant agreement No. 862834.)

Conflicts of Interest: The authors declare no conflict of interest.

\section{References}

1. Abideen, Z.; Ansari, R.; Khan, M.A. Halophytes: Potential Source of Ligno-Cellulosic Biomass for Ethanol Production. Biomass Bioenerg. 2011, 35, 1818-1822. [CrossRef]

2. Smith, C. One-Fifth of Global Farm Soil Degraded by Salt-Our World. Available online: https://ourworld.unu.edu/en/onefifth-of-global-farm-soil-degraded-by-salt (accessed on 26 February 2021).

3. Sharma, R.; Wungrampha, S.; Singh, V.; Pareek, A.; Sharma, M.K. Halophytes As Bioenergy Crops. Front. Plant Sci. $2016,7$. [CrossRef] [PubMed] 
4. Flowers, T.J.; Colmer, T.D. Salinity Tolerance in Halophytes. New Phytol. 2008, 179, 945-963. [CrossRef] [PubMed]

5. IEA Bioenergy 28th Update. Biomass Bioenerg. 2007, 31, I-XI. [CrossRef]

6. Kapler, A. Habitats of halophytes. In Halophytes and Climate Change: Adaptive Mechanisms and Potential Uses; Hasanuzzaman, M., Shabala, S., Fujita, M., Eds.; CABI: Wallingford, UK, 2019; pp. 19-37; ISBN 9781786394330.

7. Colmer, T.D.; Flowers, T.J. Flooding Tolerance in Halophytes. New Phytol. 2008, 179, 964-974. [CrossRef] [PubMed]

8. Glenn, E.P.; Brown, J.J.; Blumwald, E. Salt Tolerance and Crop Potential of Halophytes. Crit. Rev. Plant Sci. 1999, 18, 227-255. [CrossRef]

9. Buhmann, A.; Papenbrock, J. Biofiltering of Aquaculture Effluents by Halophytic Plants: Basic Principles, Current Uses and Future Perspectives. Environ. Exp. Bot. 2013, 92, 122-133. [CrossRef]

10. Sun, W.Q.; Li, X.; Ong, B. Preferential Accumulation of D-Pinitol in Acrostichum aureum Gametophytes in Response to Salt Stres. Physiol. Plant. 1999, 105, 51-57. [CrossRef]

11. Rezaie, E.E.; Haghighikhah, M.; Ghorbani, S.; Kafi, M. Effect of Seed Priming on Seed Germination Properties of Two Medicinal Species in the Presence of Salinity. J. Med. Plant Res. 2013, 7, 1234-1238.

12. Invasive Species Compendium. Available online: https:/ / www.cabi.org/isc (accessed on 13 March 2021).

13. Wilson, C. Growth Stage Modulates Salinity Tolerance of New Zealand Spinach (Tetragonia tetragonioides, Pall.) and Red Orach (Atriplex hortensis L.). Ann. Bot. 2000, 85, 501-509. [CrossRef]

14. Hasanuzzaman, M.; Nahar, K.; Alam, M.M.; Bhowmik, P.C.; Hossain, M.A.; Rahman, M.M.; Prasad, M.N.V.; Ozturk, M.; Fujita, M. Potential Use of Halophytes to Remediate Saline Soils. BioMed Res. Int. 2014, 2014, 1-12. [CrossRef]

15. O'Leary, J.W.; Glenn, E.P.; Watson, M.C. Agricultural Production of Halophytes Irrigated with Seawater. Plant Soil 1985, 89, 311-321. [CrossRef]

16. Zhu, Z.; Chen, J.; Zheng, H.-L. Physiological and Proteomic Characterization of Salt Tolerance in a Mangrove Plant, Bruguiera gymnorrhiza (L.) Lam. Tree Physiol. 2012, 32, 1378-1388. [CrossRef]

17. Varone, L.; Catoni, R.; Bonito, A.; Gini, E.; Gratani, L. Photochemical Performance of Carpobrotus edulis in Response to Various Substrate Salt Concentrations. S. Afr. J. Bot. 2017, 111, 258-266. [CrossRef]

18. Adolf, V.I.; Jacobsen, S.-E.; Shabala, S. Salt Tolerance Mechanisms in Quinoa (Chenopodium quinoa Willd.). Environ. Exp. Bot. 2013, 92, 43-54. [CrossRef]

19. Nawaz, I.; Iqbal, M.; Bliek, M.; Schat, H. Salt and Heavy Metal Tolerance and Expression Levels of Candidate Tolerance Genes among Four Extremophile Cochlearia Species with Contrasting Habitat Preferences. Sci. Total Environ. 2017, 584-585, 731-741. [CrossRef]

20. De Vos, A.C. Sustainable Exploitation of Saline Resources: Ecology, Ecophysiology and Cultivation of Potential Halophyte Crops; Wohrmann Print Service: Zutphen, The Netherlands, 2011; ISBN 9789085707462.

21. De Vos, A.C.; Broekman, R.; Groot, M.P.; Rozema, J. Ecophysiological Response of Crambe maritima to Airborne and Soil-Borne Salinity. Ann. Bot. 2010, 105, 925-937. [CrossRef]

22. Ben-Hamed, K.; Debez, A.; Chibani, F.; Abdelly, C. Salt Response of Crithmum maritimum, an Oleaginous Halophyte. Trop. Ecol. 2004, 45, 151-159.

23. Ben Amor, N.; Ben Hamed, K.; Debez, A.; Grignon, C.; Abdelly, C. Physiological and Antioxidant Responses of the Perennial Halophyte Crithmum maritimum to Salinity. Plant Sci. 2005, 168, 889-899. [CrossRef]

24. Rozema, J. An Eco-Physiological Investigation into the Salt Tolerance of Glaux maritima L. Acta Bot. Neerl. 1975, 24, 407-416. [CrossRef]

25. Tardío, J.; Pardo-De-Santayana, M.; Morales, R. Ethnobotanical Review of Wild Edible Plants in Spain. Bot. J. Linn. Soc. 2006, 152, 27-71. [CrossRef]

26. Zurayk, R.A.; Baalbaki, R. Inula Crithmoides: A Candidate Plant for Saline Agriculture. Arid Soil Res. Rehabil. 1996, 10, 213-223. [CrossRef]

27. Zhang, M.; Zhang, H.; Zheng, J.-X.; Mo, H.; Xia, K.-F.; Jian, S.-G. Functional Identification of Salt-Stress-Related Genes Using the FOX Hunting System from Ipomoea pes-caprae. J. Med. Plant Res. 2018, 19, 3446. [CrossRef] [PubMed]

28. Al Hassan, M.; Chaura, J.; López-Gresa, M.P.; Borsai, O.; Daniso, E.; Donat-Torres, M.P.; Mayoral, O.; Vicente, O.; Boscaiu, M. Native-Invasive Plants vs. Halophytes in Mediterranean Salt Marshes: Stress Tolerance Mechanisms in Two Related Species. Front. Plant Sci. 2016, 7. [CrossRef] [PubMed]

29. Agarie, S.; Shimoda, T.; Shimizu, Y.; Baumann, K.; Sunagawa, H.; Kondo, A.; Ueno, O.; Nakahara, T.; Nose, A.; Cushman, J.C. Salt Tolerance, Salt Accumulation, and Ionic Homeostasis in an Epidermal Bladder-Cell-Less Mutant of the Common Ice Plant Mesembryanthemum crystallinum. J. Exp. Bot. 2007, 58, 1957-1967. [CrossRef] [PubMed]

30. Herppich, W.B.; Huyskens-Keil, S.; Schreiner, M. Effects of Saline Irrigation on Growth, Physiology and Quality of Mesembryanthemum crystallinum L., a Rare Vege-Table Crop. J. Appl.Bot. Food Qual. 2008, 82, 47-54.

31. Theerawitaya, C.; Samphumphaung, T.; Cha-um, S.; Yamada, N.; Takabe, T. Responses of Nipa Palm (Nypa fruticans) Seedlings, a Mangrove Species, to Salt Stress in Pot Culture. Flora Morphol. Distrib. Funct. Ecol. Plants 2014, 209, 597-603. [CrossRef]

32. Koyro, H.-W. Effect of Salinity on Growth, Photosynthesis, Water Relations and Solute Composition of the Potential Cash Crop Halophyte Plantago coronopus (L.). Environ. Exp. Bot. 2006, 56, 136-146. [CrossRef]

33. Simopoulos, A.P. Omega-3 Fatty Acids and Antioxidants in Edible Wild Plants. Biol. Res. 2004, 37. [CrossRef] [PubMed] 
34. Yazici, I.; Türkan, I.; Sekmen, A.H.; Demiral, T. Salinity Tolerance of Purslane (Portulaca oleracea L.) Is Achieved by Enhanced Antioxidative System, Lower Level of Lipid Peroxidation and Proline Accumulation. Environ. Exp. Bot. 2007, 61, 49-57. [CrossRef]

35. Kodikara, K.A.S.; Jayatissa, L.P.; Huxham, M.; Dahdouh-Guebas, F.; Koedam, N. The Effects of Salinity on Growth and Survival of Mangrove Seedlings Changes with Age. Acta Bot. Bras. 2017, 32, 37-46. [CrossRef]

36. Ventura, Y.; Wuddineh, W.A.; Myrzabayeva, M.; Alikulov, Z.; Khozin-Goldberg, I.; Shpigel, M.; Samocha, T.M.; Sagi, M. Effect of Seawater Concentration on the Productivity and Nutritional Value of Annual Salicornia and Perennial Sarcocornia Halophytes as Leafy Vegetable Crops. Sci. Hortic. 2011, 128, 189-196. [CrossRef]

37. Reimann, C.; Breckle, S.-W. Salt Tolerance and Ion Relations of Salsola kali L.: Differences between ssp. tragus (L.) Nyman and ssp. ruthenica (Iljin) Soó. New Phytol. 1995, 130, 37-45. [CrossRef]

38. Messeddi, D.; Sleimi, N.; Abdelly, C. Salt tolerance in Sesuvium portulacastrum. In Plant Nutrition: Food Security and Sustainability of Agro-Ecosystems through Basic and Applied Research; Horst, W.J., Schenk, M.K., Bürkert, A., Claassen, N., Flessa, H., Frommer, W.B., Goldbach, H., Olfs, H.-W., Römheld, V., Sattelmacher, B., et al., Eds.; Developments in Plant and Soil Sciences; Springer: Dordrecht, The Netherlands, 2001; pp. 406-407; ISBN 9780306476242.

39. Słupski, J.; Achrem-Achremowicz, J.; Lisiewska, Z.; Korus, A. Effect of Processing on the Amino Acid Content of New Zealand Spinach (Tetragonia tetragonioides Pall. Kuntze): Amino Acids in New Zealand Spinach. Int. J. Food Sci. Technol. 2010, 45, 1682-1688. [CrossRef]

40. Boestfleisch, C.; Papenbrock, J. Changes in Secondary Metabolites in the Halophytic Putative Crop Species Crithmum maritimum L., Triglochin maritima L. and Halimione portulacoides (L.) Aellen as Reaction to Mild Salinity. PLoS ONE 2017, 12, e0176303. [CrossRef]

41. Koyro, H.-W.; Khan, M.; Lieth, H. Halophytic Crops: A Resource for the Future to Reduce the Water Crisis? Emir. J. Food Agric. 2011, 23, 1-16. [CrossRef]

42. Allen, J.A.; Krauss, K.W.; Hauff, R.D. Factors Limiting the Intertidal Distribution of the Mangrove Species Xylocarpus granatum. Oecologia 2003, 135, 110-121. [CrossRef] [PubMed]

43. Shabala, S.; Mackay, A. Ion Transport in Halophytes. In Advances in Botanical Research; Elsevier: New York, NY, USA, 2011; Volume 57, pp. 151-199; ISBN 9780123876928.

44. Chaudhary, D.R. Ion Accumulation Pattern of Halophytes. In Halophytes and Climate Change: Adaptive Mechanisms and Potential Uses; Hasanuzzaman, M., Shabala, S., Fujita, M., Eds.; CABI: Wallingford, UK, 2019; pp. 137-151; ISBN 9781786394330.

45. Koyro, H.-W.; Geissler, N.; Hussin, S.; Debez, A.; Huchzermeyer, B. Strategies of Halophytes to Survive in a Salty Environment. In Abiotic Stress and Plant Responses; Khan, N.A., Singh, S., Eds.; IK International: New Delhi, India, 2008 ; pp. 83-104.

46. Flowers, T.J. Physiology of Halophytes. Plant Soil 1985, 89, 41-56. [CrossRef]

47. Flowers, T.J.; Galal, H.K.; Bromham, L. Evolution of Halophytes: Multiple Origins of Salt Tolerance in Land Plants. Funct. Plant Biol. 2010, 37, 604. [CrossRef]

48. Niu, X.; Narasimhan, M.L.; Salzman, R.A.; Bressan, R.A.; Hasegawa, P.M. NaCl Regulation of Plasma Membrane H ${ }^{+}$-ATPase Gene Expression in a Glycophyte and a Halophyte. Plant Physiol. 1993, 103, 713-718. [CrossRef]

49. Parida, A.K.; Das, A.B. Salt Tolerance and Salinity Effects on Plants: A Review. Ecotoxicol. Environ. Saf. 2005, 60, 324-349. [CrossRef] [PubMed]

50. Boestfleisch, C.; Wagenseil, N.B.; Buhmann, A.K.; Seal, C.E.; Wade, E.M.; Muscolo, A.; Papenbrock, J. Manipulating the Antioxidant Capacity of Halophytes to Increase Their Cultural and Economic Value through Saline Cultivation. AoB Plants 2014, 6. [CrossRef]

51. Akinshina, N.; Oderich, K.T.; Zizov, A.A.; Aito, L.S.; Smail, S.I. Halophyte Biomass—a Promising Source of Renewable Energy. J. Arid Land Stud. 2014, 24, 231-235.

52. Galvani, A. The Challenge of the Food Sufficiency through Salt Tolerant Crops. Rev. Environ. Sci. Bio/Technol. 2007, 6, 3-16. [CrossRef]

53. Ksouri, R.; Megdiche, W.; Debez, A.; Falleh, H.; Grignon, C.; Abdelly, C. Salinity Effects on Polyphenol Content and Antioxidant Activities in Leaves of the Halophyte Cakile maritima. Plant Physiol. Biochem. 2007, 45, 244-249. [CrossRef] [PubMed]

54. Bernstein, N.; Shoresh, M.; Xu, Y.; Huang, B. Involvement of the Plant Antioxidative Response in the Differential Growth Sensitivity to Salinity of Leaves vs Roots during Cell Development. Free Radic. Biol. Med. 2010, 49, 1161-1171. [CrossRef]

55. Atkinson, N.J.; Urwin, P.E. The Interaction of Plant Biotic and Abiotic Stresses: From Genes to the Field. J. Exp. Bot. 2012, 63, 3523-3543. [CrossRef]

56. Zarrouk, M.; El Almi, H.; Youssef, N.B.; Sleimi, N.; Smaoui, A.; Miled, D.B.; Abdelly, C. Lipid Composition of Seeds of Local Halophytes: Cakile maritima, Zygophyllum album and Crithmum maritimum. In Proceedings of the Cash Crop Halophytes: Recent Studies; Lieth, H., Mochtchenko, M., Eds.; Springer: Dordrecht, The Netherlands, 2003; Volume 38, pp. 121-124.

57. Weber, D.J.; Gul, B.; Khan, M.; Williams, T.; Wayman, P.; Warner, S. Composition of Vegetable Oil from Seeds of Native Halophytic Shrubs. In Proceedings of Shrubland Ecosystem Genetics and Biodiversity; Rocky Mountain Research Center: Logan, UT, USA, 2001.

58. Glenn, E.P.; O'Leary, J.W.; Watson, M.C.; Thompson, T.L.; Kuehl, R.O. Salicornia bigelovii Torr.: An Oilseed Halophyte for Seawater Irrigation. Science 1991, 251, 1065-1067. [CrossRef] [PubMed]

59. Yajun, B.; Xiaojing, L.; Weiqiang, L. Primary analysis of four salt tolerant plants growing in Hai-He Plain, China. In Cash Crop Halophytes: Recent Studies; Lieth, H., Mochtchenko, M., Eds.; Tasks for Vegetation Science; Springer: Dordrecht, The Netherlands, 2003; Volume 38, pp. 135-138; ISBN 9789048162567. 
60. Debez, A.; Huchzermeyer, B.; Abdelly, C.; Koyro, H.-W. Current Challenges and Future Opportunities for a Sustainable Utilization of Halophytes. In Sabkha Ecosystems; Öztürk, M., Böer, B., Barth, H.-J., Clüsener-Godt, M., Khan, M.A., Breckle, S.-W., Eds.; Tasks for Vegetation Science; Springer: Dordrecht, The Netherlands, 2010; Volume 46, pp. 59-77. ISBN 9789048196722.

61. Boughalleb, F.; Denden, M. Physiological and Biochemical Changes of Two Halophytes, Nitraria retusa (Forssk.) and Atriplex halimus (L.) Under Increasing Salinity. Agric. J. 2011, 6, 327-339. [CrossRef]

62. Balasundram, N.; Sundram, K.; Samman, S. Phenolic Compounds in Plants and Agri-Industrial by-Products: Antioxidant Activity, Occurrence, and Potential Uses. Food Chem. 2006, 99, 191-203. [CrossRef]

63. Meot-Duros, L.; Le Floch, G.; Magné, C. Radical Scavenging, Antioxidant and Antimicrobial Activities of Halophytic Species. J. Ethnopharmacol. 2008, 116, 258-262. [CrossRef]

64. Bouftira, I.; Hajari, S.A.; Abdelly, C.; Sfar, S. Antioxidative And Free Radical Of Limonium axillare From Qatarian Coasts. Open Access Biomed. Publ. Post Publ. Peer Rev. 2010, 1, WMC00570. [CrossRef]

65. Medini, F. Effects of Physiological Stage and Solvent on Polyphenol Composition, Antioxidant and Antimicrobial Activities of Limonium Densiflorum. J. Med. Plants Res. 2011, 5. [CrossRef]

66. Jallali, I.; Megdiche, W.; M’Hamdi, B.; Oueslati, S.; Smaoui, A.; Abdelly, C.; Ksouri, R. Changes in Phenolic Composition and Antioxidant Activities of the Edible Halophyte Crithmum maritimum L. with Physiological Stage and Extraction Method. Acta Physiol. Plant. 2012, 34, 1451-1459. [CrossRef]

67. HLPE Biofuels and food security. A Report by the High Level Panel of Experts on Food Security and Nutrition of the Committee on World Food Security; HLPE Biofuels and Food Security: Rome, Italy, 2013.

68. Van Foreest, F. Perspectives for Biogas in Europe; Oxford Institute for Energy Studies: Oxford, UK, 2012.

69. Kamel, M.; Hammad, S.; Khalaphallah, R.; Elazeem, M.A. Halophytes and Salt Tolerant Wild Plants as a Feedstock for Biogas Production. J. BioSci. Biotechnol. 2019, 8, 151-159.

70. Bruinsma, J. The Resource Outlook to 2050: By How Much Do Land, Water Use and Crop Yields Need to Increase by 2050? Food and Agriculture Organization of the United Nations, Economic and Social Development Department: Rome, Italy, 2009.

71. Akinshina, N. Anaerobic Degradation of Halophyte Biomass for Biogas Production. J. Arid Land Stud. J. Arid Land 2012, 22, 227-230.

72. Turcios, A.E.; Papenbrock, J. Sustainable Treatment of Aquaculture Effluents-What Can We Learn from the Past for the Future? Sustainability 2014, 6, 836-856. [CrossRef]

73. Turcios, A.E.; Weichgrebe, D.; Papenbrock, J. Effect of Salt and Sodium Concentration on the Anaerobic Methanisation of the Halophyte Tripolium pannonicum. Biomass Bioenerg. 2016, 87, 69-77. [CrossRef]

74. Turcios, A.E.; Weichgrebe, D.; Papenbrock, J. Potential Use of the Facultative Halophyte Chenopodium quinoa Willd. as Substrate for Biogas Production Cultivated with Different Concentrations of Sodium Chloride under Hydroponic Conditions. Bioresour. Technol. 2016, 203, 272-279. [CrossRef] [PubMed]

75. Akinshina, N.; Azizov, A.; Karasyova, T.; Klose, E. On the Issue of Halophytes as Energy Plants in Saline Environment. Biomass Bioenerg. 2016, 91, 306-311. [CrossRef]

76. Cybulska, I.; Chaturvedi, T.; Alassali, A.; Brudecki, G.P.; Brown, J.J.; Sgouridis, S.; Thomsen, M.H. Characterization of the Chemical Composition of the Halophyte Salicornia bigelovii under Cultivation. Energy Fuels 2014, 28, 3873-3883. [CrossRef]

77. Cybulska, I.; Chaturvedi, T.; Brudecki, G.P.; Kádár, Z.; Meyer, A.S.; Baldwin, R.M.; Thomsen, M.H. Chemical Characterization and Hydrothermal Pretreatment of Salicornia bigelovii Straw for Enhanced Enzymatic Hydrolysis and Bioethanol Potential. Bioresour. Technol. 2014, 153, 165-172. [CrossRef] [PubMed]

78. Brown, J.J.; Cybulska, I.; Chaturvedi, T.; Thomsen, M.H. Halophytes for the Production of Liquid Biofuels. In Sabkha Ecosystems: Volume IV: Cash Crop Halophyte and Biodiversity Conservation; Springer: Dordrecht, The Netherlands, 2014; pp. 67-72. [CrossRef]

79. Yang, S.; Li, J.; Zheng, Z.; Meng, Z. Characterization of Spartina alterniflora as Feedstock for Anaerobic Digestion. Biomass Bioenerg. 2009, 33, 597-602. [CrossRef]

80. Deublein, D.; Angelika, S. (Eds.) Biogas from Waste and Renewable Resources-An Introduction; 3. Nachdr.; Wiley-VCH-Verl: Weinheim, Germany, 2010; ISBN 9783527318414.

81. Al Seadi, T.; Rutz, D.; Prassl, H.; Köttner, M.; Finsterwalder, T.; Volk, S.; Janssen, R. Biogas Handbook; University of Southern Denmark Esbjerg: Esbjerg, Denmark, 2008; ISBN 9788799296200.

82. Chen, G.; Zheng, Z.; Yang, S.; Fang, C.; Zou, X.; Zhang, J. Improving Conversion of Spartina alterniflora into Biogas by Co-Digestion with Cow Feces. Fuel Process. Technol. 2010, 91, 1416-1421. [CrossRef]

83. Li, R.L.; Qiu, G.Y. Spartina alterniflora: Potential Bio-Energy Source for Biofuel Production in China. AMM 2011, 142, $247-251$. [CrossRef]

84. Scarlat, N.; Dallemand, J.-F.; Fahl, F. Biogas: Developments and Perspectives in Europe. Renew. Energy 2018, 129, 457-472. [CrossRef]

85. Amon, T.; Amon, B.; Kryvoruchko, V.; Zollitsch, W.; Mayer, K.; Gruber, L. Biogas Production from Maize and Dairy Cattle Manure-Influence of Biomass Composition on the Methane Yield. Agric. Ecosyst. Environ. 2007, 118, 173-182. [CrossRef]

86. LfL Agrarökonomie. Institut für Betriebswirtschaft und Agrarstruktur: Biogasausbeuten-Datenbank. Available online: https: / / www.lfl.bayern.de/iba/energie/049711/index.php (accessed on 27 February 2021).

87. Turcios, A.E.; Weichgrebe, D.; Papenbrock, J. Biogas and Methane Production Using Biomass of the Halophyte Salicornia Spp. In Proceedings of the 14th World Congress on Anaerobic Digestion, Viña del Mar, Chile, 15 November 2015. 
88. Turcios, A.E.; Weichgrebe, D.; Papenbrock, J. Uptake and Biodegradation of the Antimicrobial Sulfadimidine by the Species Tripolium pannonicum Acting as Biofilter and Its Further Biodegradation by Anaerobic Digestion and Concomitant Biogas Production. Bioresour. Technol. 2016, 219, 687-693. [CrossRef]

89. Chen, Y.; Cheng, J.J.; Creamer, K.S. Inhibition of Anaerobic Digestion Process: A Review. Bioresour. Technol. 2008, 99, 4044-4064. [CrossRef]

90. Kugelman, I.J.; McCarty, P.L. Cation Toxicity and Stimulation in Anaerobic Waste Treatment. J. Water Pollut. Control Fed. 1965, 37, 97-116.

91. McCarty, P.L. Anaerobic Waste Treatment Fundamentals-Part Four-Process Design. Public Works 1964, 95, 95-99.

92. McCarty, P.L.; McKinney, R.E. Volatile Acid Toxicity in Anaerobic Digestion. J. Water Pollut. Control Fed. 1961, 33, $223-232$.

93. Kugelman, I.; CHIN, K.K. Toxicity, Synergism, and Antagonism in Anaerobic Waste Treatment Processes. In Anaerobic Biological Treatment Processes; Advances in Chemistry; American Chemical Society: Washington, DC, USA, 1971; Volume 105, pp. 55-90; ISBN 9780841201316.

94. Zhang, Y.; Li, L.; Kong, X.; Zhen, F.; Wang, Z.; Sun, Y.; Dong, P.; Lv, P. Inhibition Effect of Sodium Concentrations on the Anaerobic Digestion Performance of Sargassum Species. Energy Fuels 2017, 31, 7101-7109. [CrossRef]

95. Yerkes, D.W.; Boonyakitsombut, S.; Speece, R.E. Antagonism of Sodium Toxicity by the Compatible Solute Betaine in Anaerobic Methanogenic Systems. Water Sci. Technol. 1997, 36, 15-24. [CrossRef]

96. Ward, A.J.; Lewis, D.M.; Green, F.B. Anaerobic Digestion of Algae Biomass: A Review. Algal Res. 2014, 5, 204-214. [CrossRef]

97. Wang, S.; Hou, X.; Su, H. Exploration of the Relationship between Biogas Production and Microbial Community under High Salinity Conditions. Sci. Rep. 2017, 7, 1-10. [CrossRef] [PubMed]

98. Oh, G.; Zhang, L.; Jahng, D. Osmoprotectants Enhance Methane Production from the Anaerobic Digestion of Food Wastes Containing a High Content of Salt. J. Chem. Technol. Biotechnol. 2008, 83, 1204-1210. [CrossRef]

99. Kapdan, I.K.; Erten, B. Anaerobic Treatment of Saline Wastewater by Halanaerobium lacusrosei. Process Biochem. 2007, 42, 449-453. [CrossRef]

100. Kimata-Kino, N.; Ikeda, S.; Kurosawa, N.; Toda, T. Saline Adaptation of Granules in Mesophilic UASB Reactors. Int. Biodeterior. Biodegrad. 2011, 65, 65-72. [CrossRef]

101. Zhang, Y.; Alam, M.A.; Kong, X.; Wang, Z.; Li, L.; Sun, Y.; Yuan, Z. Effect of Salinity on the Microbial Community and Performance on Anaerobic Digestion of Marine Macroalgae: Effect of Salinity on Anaerobic Digestion of Marine Macroalgae. J. Chem. Technol. Biotechnol. 2017, 92, 2392-2399. [CrossRef]

102. Mottet, A.; Habouzit, F.; Steyer, J.P. Anaerobic Digestion of Marine Microalgae in Different Salinity Levels. Bioresour. Technol. 2014, 158, 300-306. [CrossRef] [PubMed]

103. Ward, A.; Ball, A.; Lewis, D. Halophytic Microalgae as a Feedstock for Anaerobic Digestion. Algal Res. 2015, 7, 16-23. [CrossRef]

104. Omil, F.; Méndez, R.; Lema, J.M. Anaerobic Treatment of Saline Wastewaters under High Sulphide and Ammonia Content. Bioresour. Technol. 1995, 54, 269-278. [CrossRef]

105. Feijoo, G.; Soto, M.; Méndez, R.; Lema, J.M. Sodium Inhibition in the Anaerobic Digestion Process: Antagonism and Adaptation Phenomena. Enzym. Microb. Technol. 1995, 17, 180-188. [CrossRef]

106. Lefebvre, O.; Quentin, S.; Torrijos, M.; Godon, J.J.; Delgenès, J.P.; Moletta, R. Impact of Increasing NaCl Concentrations on the Performance and Community Composition of Two Anaerobic Reactors. Appl. Microbiol. Biotechnol. 2007, 75, 61-69. [CrossRef]

107. Buxy, S.; Diltz, R.; Pullammanappallil, P. Biogasification of Marine Algae Nannochloropsis oculata. In Ceramic Transactions Series; Wicks, G., Simon, J., Zidan, R., Brigmon, R., Fischman, G., Arepalli, S., Norris, A., McCluer, M., Eds.; John Wiley \& Sons, Inc.: Hoboken, NJ, USA, 2013; pp. 59-67; ISBN 9781118585160.

108. Hartmann, H.; Angelidaki, I.; Ahring, B.K. Co-Digestion of the Organic Fraction of Municipal Waste With Other Waste Types. In Biomethanization of the Organic Fraction of Municipal Solid Wastes; Mata-Alvarez, J., Ed.; IWA Publishing: London, UK, 2002; pp. 181-200.

109. Alhraishawi, A.A.; Alani, W.K. The Co-Fermentation of Organic Substrates: A Review Performance of Biogas Production under Different Salt Content. J. Phys.: Conf. Ser. 2018, 1032. [CrossRef]

110. Schnürer, A.; Jarvis, ̊.. Microbiological Handbook for Biogas Plants; Avfall Sverige: Malmö, Sweden, 2010 ; ISSN 1103-4092.

111. Mshandete, A.; Kivaisi, A.; Rubindamayugi, M.; Mattiasson, B. Anaerobic Batch Co-Digestion of Sisal Pulp and Fish Wastes. Bioresour. Technol. 2004, 95, 19-24. [CrossRef] [PubMed]

112. Debez, A.; Belghith, I.; Friesen, J.; Montzka, C.; Elleuche, S. Facing the Challenge of Sustainable Bioenergy Production: Could Halophytes Be Part of the Solution? J. Biol. Eng. 2017, 11, 27. [CrossRef] [PubMed]

113. Yang, S.; Li, J.; Zheng, Z.; Meng, Z. Lignocellulosic Structural Changes of Spartina alterniflora after Anaerobic Mono- and Co-Digestion. Int. Biodeterior. Biodegrad. 2009, 63, 569-575. [CrossRef]

114. Zhang, J.; Li, W.; Lee, J.; Loh, K.-C.; Dai, Y.; Tong, Y.W. Enhancement of Biogas Production in Anaerobic Co-Digestion of Food Waste and Waste Activated Sludge by Biological Co-Pretreatment. Energy 2017, 137, 479-486. [CrossRef]

115. Nasir, Z.; Ahring, B.K.; Uellendahl, H. Enhancing the Hydrolysis Process in a Dry Anaerobic Digestion Process for the Organic Fraction of Municipal Solid Waste. Bioresour. Technol. Rep. 2020, 11. [CrossRef]

116. Rocamora, I.; Wagland, S.T.; Villa, R.; Simpson, E.W.; Fernández, O.; Bajón-Fernández, Y. Dry Anaerobic Digestion of Organic Waste: A Review of Operational Parameters and Their Impact on Process Performance. Bioresour. Technol. 2020, 299. [CrossRef] [PubMed] 
117. Sahu, P. A Comprehensive Review of Saline Effluent Disposal and Treatment: Conventional Practices, Emerging Technologies, and Future Potential. J. Water Reuse Desal. 2021, 11, 33-65. [CrossRef]

118. Uellendahl, H.; Ahring, B.K. Anaerobic Digestion as Final Step of a Cellulosic Ethanol Biorefinery: Biogas Production from Fermentation Effluent in a UASB Reactor-Pilot-Scale Results. Biotechnol. Bioeng. 2010, 107, 59-64. [CrossRef] [PubMed]

119. Santamaría-Fernández, M.; Molinuevo-Salces, B.; Lübeck, M.; Uellendahl, H. Biogas Potential of Green Biomass after Protein Extraction in an Organic Biorefinery Concept for Feed, Fuel and Fertilizer Production. Renew. Energy 2018, 129, 769-775. [CrossRef]

120. Hagman, L. How Do Biogas Solutions Influence the Sustainability of Bio-Based Industrial Systems? Linköping Studies in Science and Technology; Licentiate Thesis; Linköping University Electronic Press: Linköping, Sweden, 2018; Volume 1822; ISBN 9789176851982. 